\title{
EAO Supplement Working Group 4 - EAO CC 2015 Short implants versus sinus lifting with longer implants to restore the posterior maxilla: a systematic review
}

\author{
Thoma, D S ; Zeltner, M ; Hüsler, J ; Hämmerle, C H F ; Jung, R E
}

\begin{abstract}
OBJECTIVE: To compare short implants in the posterior maxilla to longer implants placed after or simultaneously with sinus floor elevation procedures. The focused question was as follows: Are short implants superior to longer implants in the augmented sinus in terms of survival and complication rates of implants and reconstructions, patient-reported outcome measures (PROMs) and costs? METHODS: A MEDLINE search (19902014) was performed for randomized controlled clinical studies comparing short implants ( $\leq 8 \mathrm{~mm})$ to longer implants $(>8 \mathrm{~mm})$ in augmented sinus. The search was complimented by an additional hand search of the selected papers and reviews published between 2011 and 2014. Eligible studies were selected based on the inclusion criteria, and quality assessments were conducted. Descriptive statistics were applied for a number of outcome measures. Survival rates of dental implants were pooled simply in case of comparable studies. RESULTS: Eight randomized controlled clinical trials (RCTs) comparing short implants versus longer implants in the augmented sinus derived from an initial search count of 851 titles were selected and data extracted. In general, all studies were well conducted with a low risk of bias for the majority of the analyzed parameters. Based on the pooled analyses of longer follow-ups (5 studies, 16-18 months), the survival rate of longer implants amounted to $99.5 \%$ (95\% CI: 97.6-99.98\%) and for shorter implants to 99.0\% (95\% CI: 96.4-99.8\%). For shorter follow-ups (3 studies, 8-9 months), the survival rates of longer implants are 100\% (95\% CI: 97.1-100\%) and for shorter implants $98.2 \%$ (95\% CI: 93.9-99.7\%). Complications were predominantly of biological origin, mainly occurred intraoperatively as membrane perforations, and were almost three times as higher for longer implant in the augmented sinus compared to shorter implants. PROMs, morbidity, surgical time and costs were generally in favor of shorter dental implants. All studies were performed by surgeons in specialized clinical settings. CONCLUSIONS: The outcomes of the survey analyses demonstrated predictably high implant survival rates for short implants and longer implants placed in augmented sinus and their respective reconstructions. Given the higher number of biological complications, increased morbidity, costs and surgical time of longer dental implants in the augmented sinus, shorter dental implants may represent the preferred treatment alternative.
\end{abstract}

DOI: https://doi.org/10.1111/clr.12615

Posted at the Zurich Open Repository and Archive, University of Zurich

ZORA URL: https://doi.org/10.5167/uzh-113471

Journal Article

Accepted Version

Originally published at:

Thoma, D S; Zeltner, M; Hüsler, J; Hämmerle, C H F; Jung, R E (2015). EAO Supplement Working Group 4 - EAO CC 2015 Short implants versus sinus lifting with longer implants to restore the posterior maxilla: a systematic review. Clinical Oral Implants Research, 26 Suppl:154-169.

DOI: https://doi.org/10.1111/clr.12615 


\section{EAO Supplement}

\section{Working Group 4 - EAO CC 2015}

\section{Short implants versus sinus lifting with longer implants to restore the posterior maxilla: a systematic review}

Thoma DS, ${ }^{1}$ Zeltner $M,{ }^{1}$ Hüsler ${ }^{,}{ }^{1}$ Hämmerle $\mathrm{CHF}^{1}{ }^{1}$ Jung $\mathrm{RE}^{1}$ Key words:

Systematic review, dental implant, short implant, sinus, survival rate, complication

Running title:

Short vs. longer implants in the augmented sinus

Address for correspondence: $\quad$ Daniel S. Thoma, PD Dr. med. dent.

Clinic of Fixed and Removable Prosthodontics and Dental

Material Science

University of Zurich

Plattenstrasse 11

$\mathrm{CH}-8032$ Zurich, Switzerland

Phone: +41446343257

Fax: +41446344305

e-mail: daniel.thoma@zzm.uzh.ch

${ }^{1}$ Clinic of Fixed and Removable Prosthodontics and Dental Material Science, University of Zurich, Zurich, Switzerland 


\section{Abstract}

Objective: To compare short implants in the posterior maxilla to longer implants placed after or simultaneously with sinus floor elevation procedures. The focused question was: are short implants superior to longer implants in the augmented sinus in terms of survival and complication rates of implants and reconstructions, patientreported outcome measures (PROMs) and costs?

Methods: A Medline search (1990 - 2014) was performed for randomized controlled clinical studies comparing short implants $(\leq 8 \mathrm{~mm})$ to longer implants $(>8 \mathrm{~mm})$ in augmented sinus. The search was complimented by an additional hand search of the selected papers and reviews published between 2011 and 2014. Eligible studies were selected based on the inclusion criteria, and quality assessments were conducted. Descriptive statistics were applied for a number of outcome measures. Survival rates of dental implants were pooled simply in case of comparable studies.

Results: Eight randomized controlled clinical trials (RCTs) comparing short implants versus longer implants in the augmented sinus derived from an initial search count of 851 titles were selected and data extracted. In general, all studies were well conducted with a low risk of bias for the majority of the analyzed parameters. Based on the pooled analyses of longer follow-ups (5 studies; 16-18 months), the survival rate of longer implants amounted to $99.5 \%(95 \% \mathrm{CI}: 97.6 \%-99.98 \%)$ and for shorter implants to $99.0 \%$ (95\% CI: $96.4 \%$ - 99.8\%). For shorter follow-ups (3 studies; 8-9 months), the survival rates of longer implants are $100 \%$ (95\% CI: $97.1 \%-100 \%)$ and for shorter implants $98.2 \%$ (95\% CI: $93.9 \%-99.7 \%)$. Complications were predominantly of biological origin, mainly occurred intraoperatively as membrane perforations and were almost three times as higher for longer implant in the augmented sinus compared to shorter implants. PROMs, morbidity, surgical time and costs were generally in favor of shorter dental implants. All studies were performed by surgeons in specialized clinical settings.

Conclusions: The outcomes of the survey analyses demonstrated predictably high implant survival rates for short implants and longer implants placed in augmented 
sinus and their respective reconstructions. Given the higher number of biological complications, increased morbidity, costs and surgical time of longer dental implants in the augmented sinus, shorter dental implants may represent the preferred treatment alternative. 


\section{Introduction}

Implant therapy with fixed dental prosthesis (FDPs) is considered a predictable treatment option to replace single or multiple missing teeth in partially edentulous patient rendering high implant and prosthesis survival rates (Jung et al. 2012, Pjetursson et al. 2012). These excellent long-term outcomes are mainly based on implants placed in native bone, implants with minor concomitant bone regenerative procedures and standard implant lengths. Following the extraction of teeth, significant changes of the tissue architecture occur, which in case of the posterior maxilla may lead to an insufficient bone volume to place regular length dental implants. In case of a reduced ridge height, most often, sinus elevation procedures using a lateral or transcrestal approach are chosen to enable the placement of standard length implants (Boyne \& James 1980, Summers 1994). These procedures are highly effective and may increase the ridge height up to $14 \mathrm{~mm}$ (Reinert et al. 2003). Implant survival rates for the lateral window technique and the transcrestal approach reach up $98 \%$ after 3 years of functional loading (Pjetursson et al. 2008, Tan et al. 2008). Complications, however, associated with the additional surgical intervention of performing a sinus elevation may include membrane perforation, postoperative sinusitis, partial or complete graft failure (Nkenke \& Stelzle 2009) (Stricker et al. 2003). In addition, advance surgical skills, more surgical time, increased costs and an overall higher patient morbidity may reduce patient acceptance. In order to overcome these drawbacks and limitations of longer implants placed into the augmented sinus, shorter dental implants were proposed. This treatment modality may potentially offer a variety of advantages including fewer interventions, shorter treatment time, reduced costs and a lower patient morbidity. Implant survival rates of shorter dental implants tend to be high (Annibali et al. 2012, Atieh et al. 2012, Srinivasan et al. 2014, Sun et al. 2011) with only slightly increased failure rates in the posterior maxilla and in soft bone compared to standard length implants and implants placed in the mandible (Telleman et al. 2011). Still, a clinician might be confronted with the two options of offering the patients a treatment with a 
higher complication rate and morbidity but slightly higher implant survival rates or a treatment modality with reduced costs, surgical time and morbidity but a slightly lower implant survival rate (Thoma et al. 2014). The clinical decision, for either one of the two options is based on scientific evidence, surgical skills and experience of the surgeons and the patient's preferences. Literature comparing the two treatment options in well-designed controlled clinical trials was scarce for many years, but more recent evidence suggests that both treatment options are reliable and predictably successful (Esposito et al. 2012, Gulje et al. 2014).

In order to support the clinician in the decision-making process and to inform the patient more extensively on both procedures, a systematic approach to gather literature for both treatment options is needed.

The objective of the present systematic review was to assess whether or not short implants are superior to longer implants with preceding or concomitant sinus floor augmentation in terms of

i) survival and complication rates of implants

ii) survival and complication rates of reconstructions

iii) patient-reported outcome measures (PROMs) and costs. 


\section{Material and Methods}

\section{Protocol development and eligibility criteria}

A detailed protocol was developed and followed according to the PRISMA (Preferred Reporting Items for Systematic Review and Meta-Analyses) statement (Liberati et al. 2009, Moher et al. 2009).

\section{Focused question}

Are short implants comparable to longer implants in the augmented sinus in terms of

i) morbidity and surgically-related complications

ii) clinical and radiographical outcomes?

\section{Search strategy}

An electronic Medline (PubMed) search was performed for clinical studies, including articles published from January 1, 1990 up to October 31, 2014 in the Dental literature. The search was limited to the English, German, Italian and French language. Additionally, full text articles of reviews published between January 1990 and October 2014 were obtained. An additional hand search was performed identifying relevant studies by screening these reviews and the reference list of all included publications.

\section{Search Terms}

The following search terms were applied:

("sinus" OR "maxillary sinus") AND (("floor elevation" OR "lift" OR "augmentation" OR "elevation" OR "lateral approach" OR „Cosci" OR "crestal approach" OR "transcrestal approach" OR "BAOSFE" OR "OSFE" OR "Summers technique" OR "osteotome-mediated" OR "osteotome")) OR ("short implant*" OR 
"reduced length implant*" OR "extra- short implant*")) AND ("maxilla" OR "posterior maxilla" OR "atrophic posterior maxilla"))

\section{Inclusion criteria}

Clinical publications were considered if all of the following criteria were suitable: i) human trials with a minimum amount of 20 patients, ii) randomized controlled trials (RCT) or controlled clinical trials (CCT), iii) short implants with an intrabony length of $\leq 8 \mathrm{~mm}$, iv) longer implants in combination with sinus floor elevation procedure with an intrabony length of $>8 \mathrm{~mm}, \mathrm{v}$ ) screw-type implants with a moderately rough surface, vi) implants placed within the alveolar bone and the augmented sinus, and vii) patients needed to be examined clinically.

\section{Exclusion criteria}

In vitro and preclinical studies, cohort studies, cases series, case reports, retrospective studies and reports based on questionnaires, interviews and charts were excluded from the review as well were studies not meeting all inclusion criteria.

\section{Selection of studies}

Two authors (DTH, MZL) independently screened the titles derived from this extensive search based on the inclusion criteria. Disagreements were solved by discussion. Subsequently, abstracts of all titles agreed on by both authors were obtained, and screened for meeting the inclusion criteria. If no abstract was obtainable in the database, the abstract of the printed article was used. Based on the selection of abstracts, articles were then obtained in full text. If title and abstract did not provide sufficient information regarding the inclusion criteria, the full text was obtained as well. Again, disagreements were resolved by discussion and Cohen's Kappa-coefficient was calculated as a measure of agreement between the 2 readers. 
Finally, the selection based on inclusion/exclusion criteria was made for the full text articles. For this purpose Materials and Methods, Results and Discussion of these studies were screened by two reviewers (DTH, MZL) and double-checked. Any questions that came up during the screening were discussed within the authors to aim for consensus.

\section{Data extraction and method of analysis}

For standardization purposes, 2 of the included studies were randomly selected and data extracted individually by two readers (DTH, MZL). Any disagreements were discussed to aim for consensus and to standardize the subsequent analyses. The two reviewers then independently extracted the data of all included studies using data extraction tables. All extracted data were double-checked, and any questions that came up during the screening and the data extraction were discussed within the authors to aim for consensus.

Information on the following parameters was extracted: author(s), year of publication, study design, number of patients, age range, mean age, operator(s), drop outs, implant system, number of implants, implant length, implant diameter, surgical technique, healing protocol, loading protocol, mean follow-up time of implants, implant survival, early failures, late failures, number of reconstructions, reconstruction type, mean follow-up time of reconstruction, reconstruction survival, marginal bone level changes, the number of complications (intra- and postoperative, prosthetic), patient-reported outcome measures (overall satisfaction, esthetic satisfaction, morbidity), costs, surgical time and feasibility.

The primary outcomes included survival rates of implants and reconstructions. Secondary outcomes included complication rates for implants and reconstructions, radiographic bone levels, as well as PROMs, surgical time, costs and the feasibility to perform the two procedures. 


\section{Quality Assessment}

Two reviewers (DTH, MZL) independently evaluated the methodological quality of all included studies using the Cochrane Collaboration's tool for assessing risk of bias in randomized trials (Higgins et al. 2011). Any disagreement was discussed until consensus was achieved.

\section{Statistical Analysis}

Survival rates were derived with implants as unit, hence as number of failures divided by the number of implants. The corresponding $95 \%$ confidence intervals are determined by the procedure of Blyth-Still-Casella using StatXact. Because of rather few comparable studies, the survival rates were simply pooled for the overall result in case the studies are comparable in the reported analyses. In case of too few comparable studies, no pooling of the data was applied. 


\section{Results}

\section{Study characteristics}

The electronic search identified a total of 851 titles (for details refer to Figure 1). From assessing the titles, 798 were excluded after discussion (inter-reader agreement $\mathrm{k}=0.84 \pm 0.99)$. The resulting number of abstracts obtained was 53 out of which 34 were excluded (inter-reader agreement $k=0.44 \pm 0.95$ ). Subsequently, 19 full text articles were obtained including 1 review article (Pommer et al. 2011). Hand searching provided 6 more studies (Felice et al. 2009, Felice et al. 2012, Gulje et al. 2014, Pistilli et al. 2013a, Pistilli et al. 2013b, Thoma et al. 2014). Finally, 8 articles met the inclusion criteria (Table 1 ).

\section{Exclusion of studies}

The reasons for excluding studies ( $n=16$, see reference list "List of excluded full-text articles and the reason for exclusion") after the full text was obtained were: short implant length $>8 \mathrm{~mm}$ ( 5 studies), article language in Dutch (1), no information on implant length (2), short implants placed simultaneously with a transcrestal sinus elevation procedure (2), no detailed information on short implants (2), case report (1), less than 10 patients in short implants group (1), no sinus elevation procedure in control group with longer implants (1), implants with sinus elevation procedure shorter than $8 \mathrm{~mm}(1)$.

\section{Quality assessment of the included studies}

Table 2 summarizes the results of the quality assessment of the 8 included studies. All studies were well conducted with respect to randomization, allocation, data collection and reporting resulting in a low risk for selection-, attrition- and reporting-bias. Regarding blinding of patients/surgeons (performance bias) all of the studies had a high risk-of-bias. Four studies had a high risk-of-bias from blinding of outcome assessment (detection bias): in two studies the use of an independent 
investigator was not mentioned (Gulje et al. 2014, Thoma et al. 2014), whereas in two studies different implant diameters were used for the two groups making blinding impossible (Esposito et al. 2012, Felice et al. 2009).

Other factors that mostly increased the risk-of-bias were sample size, followup duration and clinician bias. In one study sample size was adequately calculated, but a lower number of implants was included (Thoma et al. 2014). In all other studies the sample size calculation was not adequate, since a secondary outcome was used for power analysis.

With respect to group imbalance, two studies had a low risk-of-bias. In both studies, implants of the same type with an identical diameter and fixed single reconstruction were used (Gulje et al. 2014, Thoma et al. 2014). In four studies, implants of the same type with identical diameter were used, but reconstructions were splinted representing a high risk-of-bias (Esposito et al. 2012, Felice et al. 2012, Pistilli et al. 2013a, Pistilli et al. 2013b). Implants with different diameters and splinted reconstructions were used in two studies (Esposito et al. 2012, Felice et al. 2009).

\section{Included studies}

The 8 studies that met the inclusion criteria are presented in Table 1. All studies were randomized controlled trials (RCTs) published between 2009 and 2014 (Table 1). The patients were treated at University settings and/or in specialist clinics. Three of the included studies reported on a different follow-up time of the same patient population (Esposito et al. 2011, Pistilli et al. 2013a, Pistilli et al. 2013b). Since these data provided additional information and outcomes, also the publications with the short-term data were included in the analyses (Esposito et al. 2012, Felice et al. 2009, Felice et al. 2012). One study was designed as a multicenter study (Thoma et al. 2014), three studies included two centers (Esposito et al. 2012, Felice et al. 2012, Gulje et al. 2014). Two studies had a split-mouth design with both treatment modalities performed in all included patients (Esposito et al. 2012, Felice 
et al. 2009). In all other studies, one of the two treatment modalities was randomly assigned to the patients.

A total number of 406 implants was placed (group short $=197$ implants; group longer implants with a lateral window sinus elevation procedure $=209$ implants) in 217 patients with a mean age of 54 years (group short $=127$ patients; groups longer implants with a lateral window sinus elevation procedure $=125$ patients). The length of the short implants was 5 or $6 \mathrm{~mm}$ and the diameter 4,5 or 6 $\mathrm{mm}$. In the groups with longer implants, sinus elevation procedures were performed simultaneously with implant placement in 4 studies, and staged in 1 study (Felice et al. 2009). Implant lengths ranged between 10 and $15 \mathrm{~mm}$, whereas the diameter was $4 \mathrm{~mm}$. The reported drop-out rates varied between $0 \%$ and $5 \%$. Except for one study, where implants were left for submerged or transmucosal healing depending on the clinician's preference (Thoma et al. 2014), all implants were left for submerged healing. In three studies, provisional restorations were inserted 4 months after implant placement, followed 4 months later with the final reconstructions (Esposito et al. 2012, Felice et al. 2009, Felice et al. 2012). No provisional restorations were used in 2 studies. In these trials, the final reconstructions were inserted 4 months (Gulje et al. 2014) and 6 months (Thoma et al. 2014) after implant placement. The follow-up ranged between 8 to 18 months after implant placement and 0 to 12 months after insertion of the final reconstruction. The mean follow-up after insertion of the final reconstruction was 8 months reported by three studies (Esposito et al. 2012, Gulje et al. 2014, Thoma et al. 2014). (Table 3)

\section{Survival rates of implants and reconstructions}

In general, implant and reconstruction survival rates were high, but follow-up times were short. Three dental implants were lost during the follow-up. This encompassed one short implant prior to loading (Felice et al. 2009); one short implant after loading (Felice et al. 2012) and one longer implant after loading (Esposito et al. 2011). 
The reported implant survival rates for both groups and implants ranged between $97 \%$ and $100 \%$ after mean observation periods of 8 to 18 months (Figure 2 \& 3). Due to heterogeneity in terms of mean and only short-term observation periods no meta-analyses were conducted. Pooled data for the 5 studies reporting on longer-term observation periods (16-18 months) revealed a mean implant survival rate of $99.0 \%$ ( $95 \%$ confidence interval $96.4 \%$ to $99.8 \%$ ) for shorter implants (Figure 2B) and $99.5 \%$ (95\% C.I. $97.6 \%$ to $100.0 \%$ ) for longer implants in the augmented sinus (Figure 2A) (Esposito et al. 2011, Gulje et al. 2014, Pistilli et al. 2013a, Pistilli et al. 2013b, Thoma et al. 2014). The pooled data for the three studies reporting short-term observation periods (9 to 9 months) revealed a mean implant survival rate of $98.2 \%$ ( $95 \%$ C.I. $93.9 \%$ to $99.7 \%$ ) for shorter implants (Figure 3B) and of $100 \%$ ( $95 \%$ C.I. $97.1 \%$ to $100 \%$ ) for longer implants in the augmented sinus (Figure 3A) (Esposito et al. 2012, Felice et al. 2009, Felice et al. 2012) (Table 3).

The survival rates of the reconstructions were not specified in all the studies. Reported observation periods ranged between 0 and 12 months (post insertion of the final reconstruction). Due to these short follow-up times and heterogeneity between the studies, no meta-analyses were conducted. The reported survival rates of the reconstructions varied between $97 \%$ and $100 \%$ for shorter implants and $100 \%$ for longer implants in the augmented sinus. In the three studies with the longest follow-up (12 months), all reconstructions were still in place rendering a $100 \%$ survival rate for both treatment modalities (Gulje et al. 2014, Pistilli et al. 2013a, Thoma et al. 2014). (Table 4)

\section{Complications}

All included studies assessed biological and prosthetic complications. Identical data reported in studies representing a longer follow-up of the same patient population were included only once (Esposito et al. 2011, Pistilli et al. 2013a, Pistilli et al. 2013b). A total of 12 events were observed in the groups with shorter implants 
compared to 24 events in the groups with longer implants with a lateral window sinus floor elevation procedure.

Out of the 12 complications (groups short), 8 were biological and 4 prosthetic. The data on biological complications derived from three studies (Esposito et al. 2011, Felice et al. 2009, Thoma et al. 2014). Five complications occurred intraoperatively, whereas 3 were postoperative complications. Two studies observed prosthetic complications consisting of an abutment screw loosening, an abutment screw fracture, one failing abutment and one failing provisional restoration (Pistilli et al. 2013b, Thoma et al. 2014). The most frequent complications in the groups with longer implants with a lateral window sinus elevation procedure occurred intraoperatively (16 out of 24 ). In one study 6 intraoperative complications were not specified (Thoma et al. 2014), in three studies 10 membrane perforations were observed (Esposito et al. 2012, Felice et al. 2009, Felice et al. 2012). In addition, 5 postoperative complications were observed totaling up to 21 biological complications. Only 3 out of 24 events were prosthetic complications consisting of two abutment loosenings and one failing abutment. All these complications were reported in one study (Thoma et al. 2014). In one clinical study, neither biological nor prosthetic complications were reported for both treatment modalities (Gulje et al. 2014).

In most of the studies the differences between the two groups with respect to complication rates were statistically not significant. Only one study detected a statistically significant difference in favour of group short (Felice et al. 2012). (Table 5)

\section{Radiographic outcomes}

In three studies the changes of the marginal bone levels were reported (Gulje et al. 2014, Pistilli et al. 2013a, Pistilli et al. 2013b).

No statistically significant differences with a mean loss of $0.1 \mathrm{~mm}$ for both groups were reported during a 12-mont follow-up (insertion of reconstruction to the one-year follow-up examination) in one of the studies with the longest follow-up and 
using platform-shifted two-piece dental implants (Gulje et al. 2014). In two other studies by the same group of surgeons significant changes in marginal bone levels were reported from implant placement to loading and up to 12 months of loading (Pistilli et al. 2013a, Pistilli et al. 2013b). In the first study, a mean marginal bone loss of $0.47 \mathrm{~mm}$ for short implants and of $0.57 \mathrm{~mm}$ for longer implants in the augmented sinus were observed from implant placement to loading four months later, whereas from implant placement to 12 months after loading the bone loss increased to $1.02 \mathrm{~mm}$ and $1.09 \mathrm{~mm}$ respectively (Pistilli et al. 2013a). In the second study, both groups lost marginal peri-implant bone from implant placement to loading 4 months later (group short $=0.46 \mathrm{~mm}$; group longer implants with a lateral window sinus elevation procedure $=0.58 \mathrm{~mm}$ ) and to 12 months after loading (group short $=0.87 \mathrm{~mm}$; group longer implants with a lateral window sinus elevation procedure $=1.15 \mathrm{~mm}$ ) (Pistilli et al. 2013b).

In all of the studies no statistically significant differences in marginal bone level changes were reported between short implants and longer implants placed in the augmented sinus. (Table 5)

\section{Patient reported outcome measures (PROMs)}

Four studies provided data on PROMs and morbidity revealing heterogeneity regarding the assessment tools.

A questionnaire was handed to the patients in one study to evaluate patient satisfaction pre-surgically and 12 month after loading. Patient's satisfaction significantly improved for both treatment modalities. At the 12 -month evaluation no statistically significant difference was observed between the two groups (overall satisfaction group short $=9.5$ out of 10 ; overall satisfaction group longer implants with a lateral window sinus elevation procedure $=9.2$ out of 10 ) (Gulje et al. 2014). A second study with a similar study design assessed PROMs and morbidity with a standardized questionnaire (OHIP-49 = Oral Health Impact Profile) pre-surgically, at suture removal, at the day of insertion of the final reconstruction and at 12 months 
post loading. This questionnaire covered eight different dimensions (functional limitation, physical pain, psychological discomfort, physical disability, physiological disability, social disability, handicap and an overall score). For both groups, the mean OHIP severity scores were higher at suture removal compared to baseline and to insertion of the reconstruction indicating a negative impact of the surgical procedures on the quality of life during the first $7-14$ days after surgery. Regarding changes of OHIP severity scores, a more significant decrease was observed for longer implants in the augmented sinus suggesting a negative impact of the additional sinus floor elevation procedure on quality of life (Thoma et al. 2014). In the two remaining studies with a split-mouth design, patients were asked about their preference regarding the two treatment modalities. In the first study the patients had no preference (Felice et al. 2009). In the second study 15 out of 20 patients preferred short implants, whereas 5 patients described both treatments as equally acceptable. This difference was reported to be statistically significant (Esposito et al. 2012). (Table 6)

\section{Surgical time and costs}

Only one study assessed the duration of the surgeries and the price of both treatment modalities (Thoma et al. 2014).

The reported mean surgical time was $52.6 \mathrm{~min}$ in group short compared to $74.6 \mathrm{~min}$ in the group with longer implants concomitant with a lateral window sinus elevation procedure. The price of both treatment modalities was calculated limited to the surgery. The mean price in group short was 941 EUR, while in group longer implants with a lateral window sinus floor elevation procedure the mean price amounted to 1944 EUR. The differences between the two groups were statistically significant for both surgical time and costs (Thoma et al. 2014). (Table 6) 


\section{Feasibility}

All surgical procedures were performed by specialists either in private practices, universities or specialized clinics. Three studies reported data including different centers (Esposito et al. 2012, Felice et al. 2012, Gulje et al. 2014). None of the studies revealed or did report any statistically significant differences between the centers. (Table 6) 


\section{Discussion}

The present systematic review revealed that i) the number of publications in this field is increasing with well-designed RCTs, ii) the included RCTs report shortterm follow-up data only, iii) the quality of reporting of the studies represented a low risk of bias in terms of randomization, allocation, data collection and reporting of results, iv) implant and reconstruction survival rates for shorter implants and implants in conjunction with a sinus floor elevation procedure are high, v) complications were mainly detected intraoperatively and related to sinus elevation procedures, vi) radiographically assessed marginal bone levels did not show any significant differences between the two treatment modalities, vii) PROMs in general favor the treatment groups with shorter dental implants, viii) surgical time and treatment costs were in favor of shorter dental implants and, iv) the ability of perform both procedures is currently limited to experienced surgeons in specialized clinics and universities.

\section{Quality assessment of included studies}

All included studies were designed as RCTs and revealed a low risk of bias for a number of parameters (selection-, attrition- and reporting-bias). The highest risk of bias was observed for a lack of or not reporting of an appropriate sample size calculation and a relatively short follow-time. Taken into account limitations of a relatively low number of included studies and the above-mentioned high risks of bias for some of the parameters, the evidence coming out of the eight included studies is robust. This allows making at least careful clinical recommendations that both treatment modalities could be equally successful on a short-term basis. 


\section{Survival rates of dental implants}

Survival rates of dental implants are reported to be high for shorter dental implants placed in various locations of the mandible and the maxilla as demonstrated by an increasing number of systematic reviews (Annibali et al. 2012, Atieh et al. 2012, Srinivasan et al. 2014, Sun et al. 2011). Nevertheless, clinicians were afraid of a number of potential limitations that could potentially be associated with the use of shorter dental implants. This mainly included the risk for biomechanical complications due to a higher $\mathrm{n}$ ratio (C/I) and a higher failure rate in areas with soft bone, predominantly present in the posterior area of the maxilla. A potentially greater C/I ratio has, so far, not been demonstrated to result in higher failure rates, a greater extent of marginal bone loss, an increased number of biological complications (Quaranta et al. 2014). However, according to a systematic review a slightly higher failure rates were observed for shorter dental implants in the maxilla compared to the mandible (Telleman et al. 2011). In contrast, longer dental implants placed in the augmented sinus may as well have an increased failure rate (of up to $17 \%$ within three years) compared to implants placed in native bone (Pjetursson et al. 2008). Due to heterogeneity of the included studies in the present systematic review, no meta-analyses could be performed. However, none of the studies did report any statistically significant differences in terms of mean survival rates between shorter dental implants and longer implant placed in the augmented sinus. The calculated mean survival rate of shorter dental implant was $99.0 \%$ (95\% C.I. $96.4 \%$ to $99.8 \%$ ) and therefore close to the mean survival rate of longer implants in the augmented sinus (99.5\%; 95\% C.I. $97.6 \%$ to $100.0 \%$ ). Restrictions and limitations still include i) that all studies had a relatively short observation period ranging between 8 and 18 months, ii) that in all, but one clinical study, shorter dental implants were splinted and not restored by single crowns and, iii) no data on crown-to-implant ratios. However, a positive or negative effect of splinting dental implants has not been demonstrated either in terms of survival rates. 


\section{Survival rates of reconstructions}

Dental implants restored with single crowns (SCI) or fixed dental prostheses (FDP) are documented with high implant survival rates ranging between $96.3 \%$ (95\% CI: $94.2 \%-97.6 \%$ ) after 5 years for SCIs and $93.6 \%$ (95 percent C.I.: $90.7 \%$ - 95.6\%) for FDPs (Jung et al. 2012, Pjetursson et al. 2012). In the current systematic review, survival rates of the reconstructions could not be pooled and no meta-analysis could be performed due to a large heterogeneity between the studies in terms of the type and material of the reconstructions as well as varying observation periods that mainly included rather short-term observation periods up to 12 months. Similarly to the survival rates of implants, none of the included studies reported significant differences between the groups with shorter or longer implants placed in the augmented sinus. The range of survival rates was $97 \%-100 \%$ (shorter dental implants) and $100 \%$ for longer dental implants in the augmented sinus.

\section{Complications}

Complications associated with dental implant therapy may occur perioperatively and postoperatively. In clinical studies dealing with a reduced ridge height in the posterior maxilla, the most common complication to expect is the perforation of Schneiderian membrane (Pjetursson et al. 2008). For shorter dental implants, a rupture of the sinus membrane may predominantly occur during implant placement with the tip of a drill or the dental implant protruding into the sinus cavity. In case of a sinus floor elevation procedure, the most common complication with an event rate of up to $20 \%$ may mainly occur during the sinus floor elevation procedure. In the present systematic review, a total number of 36 complications in 252 surgical interventions was reported. It was shown that shorter dental implant only accounted for $33 \%$ of these complications, thereby demonstrating that with a sinus elevation procedure, the risk of complications increases by $100 \%$ (in $20 \%$ of surgical interventions/24 complications compared to an incidence of $10 \%$ of surgical interventions/12 complications with shorter dental implants). Biological complications 
associated with shorter dental implants ( 5 intra-operative and 3 postoperative complications) were much less common than with longer dental implants with a sinus elevation procedure (21 complications). The majority of the complications were attributed to membrane perforations that occurred intra-operatively (16 complications). This resulted in a roughly three times higher risk of having an intraoperative complication for longer dental implants (16) compared to shorter dental implants (5). In perspective, membrane perforations, even though being reported as a complication, may not necessarily compromise the implant-related outcomes. Postoperative complications were not observed in such a high frequency (3.6\%) and almost similar between the two treatment modalities. According to systematic reviews on SCIs and FDPs, prosthetic complications are frequent (up to $9 \%$ for SCIs and up to $25 \%$ over 5 years for FDPs) (Jung et al. 2012, Pjetursson et al. 2012). The relatively low number of technical complications in the present systematic review mainly derives from the fact that the prosthetic follow-up was only up to 12 months of loading and the limited number of studies that even reported prosthetic outcomes. These limitations did not allow pooling the data, the higher complication rates for longer dental implants were therefore only reported descriptively.

\section{Radiographic outcomes}

Marginal bone levels and bone level changes depend on a number of parameters that mainly include i) implant type, ii) implant design, iii) implant surface and, iv) implant diameter. The included studies reported on three different implant brands only. In all but one study that reported short and longer-term data (Esposito et al. 2011, Felice et al. 2009), the diameter of short and longer dental implants had a similar dimension. Keeping the same implant diameter for test and control groups excludes a further parameter that might affect differences in terms of marginal bone level changes. Still, heterogeneity between the studies did not allow pooling the data for a number of reasons. The individually reported marginal bone level changes in 
each of the studies did not show any statistically significant differences between the two treatment modalities, but depending on the implant brand and type and the observation period varying levels of the marginal bone. Data of the study with the longest follow-up (18 months after implant placement; (Gulje et al. 2014)) demonstrated a minimal loss of bone irrespective of the treatment modality and in accordance to one-year data for using the same implant system with implant placed in native bone in the mandible and maxilla (Gulje et al. 2013).

\section{Patient-reported outcome measures (PROMs)}

From a patient perspective, survival rates of dental implants and reconstructions as well as marginal bone level changes are not the only relevant outcome parameters. Upon discussion with a patient explaining different treatment options, a clinician's is confronted with questions regarding intra-, peri- and postoperative morbidity. This information regarding parameters such as morbidity belong to a comprehensive treatment planning and will likely contribute to the final decision-making for a specific therapy. Out of 5 included studies in the present systematic review, four studies reported data for PROMs using different assessment tools (individual questionnaires, OHIP-49 questionnaires (Esposito et al. 2012, Felice et al. 2009, Gulje et al. 2014, Thoma et al. 2014). The data demonstrate in three of the studies, advantages with less morbidity associated with the use of shorter dental implants compared to the control groups with more extensive bone augmentation procedures (sinus elevation) (Esposito et al. 2012, Felice et al. 2009, Thoma et al. 2014). The results of the studies are difficult to compare since in some of the studies, a split-mouth design was chosen, whereas in other two separate groups were included. In addition, the number of implants placed in each patient differed within the same groups of patients in some of the studies: i.e., some patients received one implant whereas other received 2-3 implants. This imbalance and variations within the same patient population probably reduced the probability to obtain a clearer result in terms of less morbidity associated with shorter dental implants. At least, 
one study, however, reported that 15 out of 20 patients would prefer the therapy with shorter dental implants (Esposito et al. 2012).

\section{Surgical time and costs}

One single study only assessed further parameter relevant in the decisionmaking for one of the two treatment options (Thoma et al. 2014). Surgical time was increased by $50 \%$ when a sinus augmentation procedure was performed compared to the use of just a short dental implant. This difference in time may be directly related to PROMs and morbidity and may in part account for a higher rate of complications intra- and postoperatively as demonstrated by previous studies. In one particular study, a correlation between surgical time and complications was reported. A shorter treatment time was associated with lower VAS scores in PROM parameters (Tan et al. 2014).

Financial aspects play an important role when it comes to the decisionmaking process for a specific treatment options and complement other important factors such as expected complications, success rates, potential biological and aesthetic risks and PROMs. In the present systematic review, only one study reported on the individual costs for the two treatment options revealing statistically significant differences in favor of shorter dental implant (Thoma et al. 2014). This treatment option accounted for only half the costs compared to longer implants in the augmented sinus. Leaving the financial situation of the patient aside, the costbenefit ratio of a specific treatment modality may likely contribute in the decisionmaking for a treatment plan to be executed. The cost-benefit ratio, however, does not only include costs derived from the surgical procedure, but may also include costs for future failures and complications. These data, however, are not documented for the two treatment modalities so far. 


\section{Feasibility}

As stated above, beside general outcome measures such as implant and reconstruction survival rates and marginal bone levels, other important aspects play a crucial role in the decision-making process for a specific treatment option from a patient's perspective. From a clinician's side, education and acquired skills over the years may contribute during the patient information and lead to the final decision for a treatment plan (Nisand \& Renouard 2014). Previous studies revealed that inexperienced surgeons have twice as many implant failures compared to experienced surgeons (Truhlar et al. 1994). One might assume that a sinus elevation procedure requires more advanced surgical skills than standard implant placement and therefore increase the number of complications. In order to assess the feasibility of performing the two types of surgical interventions, the present review sought to evaluate the experience and education the surgeons. According to the data reported, all surgical procedures were performed by specialists either at private practices, university settings or in specialized clinics. Speculating that sinus augmentation surgeries require more surgical skills, the use of shorter dental implants may open implant therapy to a broader field of surgeons and subsequently to a broader patient population.

\section{Limitations of the systematic review}

The present systematic review covered a new research area and the number of publications found through online and hand search was limited. Only one database "PubMed" was selected for the electronic search. Keeping in mind that more databases exist, one might speculate that more scientific data exist. This was, however, compensated by an additional hand search that included the screening of review articles, and the reference lists of all obtained full text articles. 


\section{Conclusion}

The outcomes of the present systematic review demonstrated on the basis of a limited number of studies with short-term follow-up that i) both treatment options are safe and predictable for implant therapy in the atrophied maxilla, ii) implant and reconstruction survival rates are high, iii) biological complications are frequent, but mainly associated with longer implant in the augmented sinus, iv) PROMs and morbidity, costs and surgical time are in favor of shorter dental implants.

\section{Clinical recommendations}

Considering high implant and reconstruction survival rates observed in 8 RCTs with a follow-up of maximal 18 months, both treatment modalities can be recommended for implant therapy in the posterior maxilla with a limited ridge height. Clinicians must be aware that complications may occur to various extents, most notably intraoperative perforations of the Schneiderian membrane during sinus floor elevation procedures. Limitations apply, however, that the feasibility to perform both procedures is currently restricted to specialists at universities and private practices, at least for the option longer dental implant in conjunction with a sinus floor elevation procedure.

\section{Research recommendations}

The outcomes of the present systematic review are based on a small number of well-designed studies with short-term follow-up. Whilst basic biological parameters (e.g. marginal bone levels, biological complications) were frequently reported in the studies, prosthetic outcome measures were inconsistently analyzed or not documented. In addition, important outcome measures such as PROMs are infrequently and inconsistently used without much standardization. There is a strong 
need to examine patients included in these and further well-designed studies on a long-term basis. 
Conflict of interest, source of funding and

\section{acknowledgments}

The authors report no conflict of interest and are grateful to Gisela Müller, Study Monitor, Clinic of Fixed and Removable Prosthodontics and Dental Material Science, University of Zurich, for her help in the preparation of the manuscript. This manuscript was funded by the Clinic of Fixed and Removable Prosthodontics and Dental Material Science, University of Zurich. 


\section{List of Reviews}

Pommer, B., Frantal, S., Willer, J., Posch, M., Watzek, G. \& Tepper, G. (2011) Impact of dental implant length on early failure rates: A meta-analysis of observational studies. Journal of Clinical Periodontology 38: 856-863.

\section{Included articles}

Esposito, M., Cannizzaro, G., Soardi, E., Pistilli, R., Piattelli, M., Corvino, V. \& Felice, P. (2012) Posterior atrophic jaws rehabilitated with prostheses supported by 6 $\mathrm{mm}$-long, $4 \mathrm{~mm}$-wide implants or by longer implants in augmented bone. Preliminary results from a pilot randomised controlled trial. European Journal of Oral Implantology 5: 19-33.

Esposito, M., Pellegrino, G., Pistilli, R. \& Felice, P. (2011) Rehabilitation of postrior atrophic edentulous jaws: Prostheses supported by $5 \mathrm{~mm}$ short implants or by longer implants in augmented bone? One-year results from a pilot randomised clinical trial. European Journal of Oral Implantology 4: 21-30.

Felice, P., Checchi, V., Pistilli, R., Scarano, A., Pellegrino, G. \& Esposito, M. (2009) Bone augmentation versus $5-\mathrm{mm}$ dental implants in posterior atrophic jaws. Four-month post-loading results from a randomised controlled clinical trial. European Journal of Oral Implantology 2: 267-281.

Felice, P., Pistilli, R., Piattelli, M., Soardi, E., Corvino, V. \& Esposito, M. (2012) Posterior atrophic jaws rehabilitated with prostheses supported by $5 \times 5 \mathrm{~mm}$ implants with a novel nanostructured calcium-incorporated titanium surface or by longer implants in augmented bone. Preliminary results from a randomised controlled trial. European Journal of Oral Implantology 5: 149161.

Gulje, F. L., Raghoebar, G. M., Vissink, A. \& Meijer, H. J. (2014) Single crowns in the resorbed posterior maxilla supported by either $6-\mathrm{mm}$ implants or by $11-\mathrm{mm}$ implants combined with sinus floor elevation surgery: A 1-year randomised controlled trial. European Journal of Oral Implantology 7: 247-255.

Pistilli, R., Felice, P., Cannizzaro, G., Piatelli, M., Corvino, V., Barausse, C., Buti, J., Soardi, E. \& Esposito, M. (2013a) Posterior atrophic jaws rehabilitated with prostheses supported by $6 \mathrm{~mm}$ long $4 \mathrm{~mm}$ wide implants or by longer implants in augmented bone. One-year post-loading results from a pilot randomised controlled trial. European Journal of Oral Implantology 6: 359372. 
Pistilli, R., Felice, P., Piattelli, M., Gessaroli, M., Soardi, E., Barausse, C., Buti, J. \& Corvino, V. (2013b) Posterior atrophic jaws rehabilitated with prostheses supported by $5 \times 5 \mathrm{~mm}$ implants with a novel nanostructured calciumincorporated titanium surface or by longer implants in augmented bone. Oneyear results from a randomised controlled trial. European Journal of Oral Implantology 6: 343-357.

Thoma, D. S., Haas, R., Tutak, M., Garcia, A., Schincaglia, G. P. \& Hämmerle, C. H. F. (2014) Randomized controlled multicenter study comparing short dental implants $(6 \mathrm{~mm})$ versus longer dental implants $(11-15 \mathrm{~mm})$ in combination with sinus floor elevation procedures. Part 1: Demographics and patientreported outcomes at 1 year of loading. Journal of Clinical Periodontology.

\section{Excluded articles and reason for exclusion}

Bahat O, Sullivan RM, Smidt A (2012). Placement of Branemark Mk IV implants in compromised and grafted bone: radiographic outcome of 61 sites in 27 patients with 3- to 7-year follow-ups. Quintessence International 43, 293-303. [Exclusion criteria: implant length $>8 \mathrm{~mm}$ ]

Barone A, Orlando B, Tonelli P, Covani U (2011). Survival rate for implants placed in the posterior maxilla with and without sinus augmentation: a comparative cohort study. Journal of Periodontology 82, 219-226. [Exclusion criteria: no information on implant length]

Cannizzaro G, Felice P, Leone M, Viola P, Esposito M (2009). Early loading of implants in the atrophic posterior maxilla: lateral sinus lift with autogenous bone and Bio-Oss versus crestal mini sinus lift and 8-mm hydroxyapatitecoated implants. A randomised controlled clinical trial. European Journal of Oral Implantology 2, 25-38. [Exclusion criteria: short implants in combination with transcrestal sinus elevation]

Cannizzaro G, Felice P, Minciarelli AF, Leone M, Viola P, Esposito M (2013). Early implant loading in the atrophic posterior maxilla: 1-stage lateral versus crestal sinus lift and $8 \mathrm{~mm}$ hydroxyapatite-coated implants. A 5-year randomised controlled trial. European Journal of Oral Implantology 6, 13-25. [Exclusion criteria: short implants in combination with transcrestal sinus elevation] 
de Lange GL, Kuiper L, Blijdorp PA, Hutter W, Mulder WF (1997). [Five-year evaluation of implants in the resorbed maxilla]. Nederlands Tijdschrift Voor Tandheelkunde 104, 274-276. [Exclusion criteria: language: netherlands]

Degidi M, Daprile G, Piattelli A, Carinci F (2007). Evaluation of factors influencing resonance frequency analysis values, at insertion surgery, of implants placed in sinus-augmented and nongrafted sites. Clinical Implant Dentistry and Related Research 9, 144-149. [Exclusion criteria: no information on implant length]

Ellegaard B, Baelum V, Kolsen-Petersen J (2006). Non-grafted sinus implants in periodontally compromised patients: a time-to-event analysis. Clinical Oral Implants Research 17, 156-164. [Exclusion criteria: no detailed information on short implants]

Felice P, Soardi E, Pellegrino G, Pistilli R, Marchetti C, Gessaroli M, Esposito M (2011). Treatment of the atrophic edentulous maxilla: short implants versus bone augmentation for placing longer implants. Five-month post-loading results of a pilot randomised controlled trial. European Journal of Oral Implantology 4, 191-202. [Exclusion criteria: implants longer than 8mm]

Johansson B, Back T, Hirsch JM (2004). Cutting torque measurements in conjunction with implant placement in grafted and nongrafted maxillas as an objective evaluation of bone density: a possible method for identifying early implant failures? Clinical Implant Dentistry and Related Research 6, 9-15. [Exclusion criteria: includes implants in anterior maxilla]

Naert I, Koutsikakis G, Duyck J, Quirynen M, Jacobs R, van Steenberghe D (2002). Biologic outcome of implant-supported restorations in the treatment of partial edentulism. part I: a longitudinal clinical evaluation. Clinical Oral Implants Research 13, 381-389. [Exclusion criteria: less than 10 patients (short implants)]

Nedir R, Bischof M, Briaux JM, Beyer S, Szmukler-Moncler S, Bernard JP (2004). A 7year life table analysis from a prospective study on ITI implants with special emphasis on the use of short implants. Results from a private practice. Clinical Oral Implants Research 15, 150-157. [Exclusion criteria: no sinus elevation procedures]

Palarie V, Bicer C, Lehmann KM, Zahalka M, Draenert FG, Kammerer PW (2012). Early outcome of an implant system with a resorbable adhesive calciumphosphate coating--a prospective clinical study in partially dentate patients. Clinical Oral Investigations 16, 1039-1048. [Exclusion criteria: no detailed information on short implants] 
Perelli M, Abundo R, Corrente G, Saccone C (2012). Short (5 and $7 \mathrm{~mm}$ long) porous implants in the posterior atrophic maxilla: a 5-year report of a prospective single-cohort study. European Journal of Oral Implantology 5, 265-272. [Exclusion criteria: implants no longer than $7 \mathrm{~mm}$ ]

Rasmusson L, Thor A, Sennerby L (2012). Stability evaluation of implants integrated in grafted and nongrafted maxillary bone: a clinical study from implant placement to abutment connection. Clinical Implant Dentistry and Related Research 14, 61-66. [Exclusion criteria: implant length $>8 \mathrm{~mm}$ ]

Schlesinger CD (2014). Short implants: a viable alternative to sinus augmentation. Dentistry Today 33, 128, 130, 132-123. [Exclusion criteria: case report]

Uckan S, Deniz K, Dayangac E, Araz K, Ozdemir BH (2010). Early implant survival in posterior maxilla with or without beta-tricalcium phosphate sinus floor graft. Journal of Oral and Maxillofacial Surgery 68, 1642-1645. [Exclusion criteria: implant length $>8 \mathrm{~mm}$ ]

\section{References}

Annibali, S., Cristalli, M. P., Dell'Aquila, D., Bignozzi, I., La Monaca, G. \& Pilloni, A. (2012) Short dental implants: A systematic review. Journal of Dental Research 91: 25-32.

Atieh, M. A., Zadeh, H., Stanford, C. M. \& Cooper, L. F. (2012) Survival of short dental implants for treatment of posterior partial edentulism: A systematic review. International Journal of Oral and Maxillofacial Implants 27: 1323-1331.

Boyne, P. J. \& James, R. A. (1980) Grafting of the maxillary sinus floor with autogenous marrow and bone. Journal of Oral Surgery 38: 613-616.

Esposito, M., Cannizzaro, G., Soardi, E., Pistilli, R., Piattelli, M., Corvino, V. \& Felice, P. (2012) Posterior atrophic jaws rehabilitated with prostheses supported by $6 \mathrm{~mm}$ long, $4 \mathrm{~mm}$-wide implants or by longer implants in augmented bone. Preliminary 
results from a pilot randomised controlled trial. European Journal of Oral Implantology 5: 19-33.

Esposito, M., Pellegrino, G., Pistilli, R. \& Felice, P. (2011) Rehabilitation of postrior atrophic edentulous jaws: Prostheses supported by $5 \mathrm{~mm}$ short implants or by longer implants in augmented bone? One-year results from a pilot randomised clinical trial. European Journal of Oral Implantology 4: 21-30.

Felice, P., Checchi, V., Pistilli, R., Scarano, A., Pellegrino, G. \& Esposito, M. (2009) Bone augmentation versus $5-\mathrm{mm}$ dental implants in posterior atrophic jaws. Fourmonth post-loading results from a randomised controlled clinical trial. European Journal of Oral Implantology 2: 267-281.

Felice, P., Pistilli, R., Piattelli, M., Soardi, E., Corvino, V. \& Esposito, M. (2012) Posterior atrophic jaws rehabilitated with prostheses supported by $5 \times 5 \mathrm{~mm}$ implants with a novel nanostructured calcium-incorporated titanium surface or by longer implants in augmented bone. Preliminary results from a randomised controlled trial. European Journal of Oral Implantology 5: 149-161.

Gulje, F., Abrahamsson, I., Chen, S., Stanford, C., Zadeh, H. \& Palmer, R. (2013) Implants of $6 \mathrm{~mm}$ vs. $11 \mathrm{~mm}$ lengths in the posterior maxilla and mandible: A 1-year multicenter randomized controlled trial. Clinical Oral Implants Research 24: 13251331.

Gulje, F. L., Raghoebar, G. M., Vissink, A. \& Meijer, H. J. (2014) Single crowns in the resorbed posterior maxilla supported by either $6-\mathrm{mm}$ implants or by $11-\mathrm{mm}$ implants combined with sinus floor elevation surgery: A 1-year randomised controlled trial. European Journal of Oral Implantology 7: 247-255.

Higgins, J. P., Altman, D. G., Gotzsche, P. C., Juni, P., Moher, D., Oxman, A. D., Savovic, J., Schulz, K. F., Weeks, L., Sterne, J. A., Cochrane Bias Methods, G. \& Cochrane Statistical Methods, G. (2011) The cochrane collaboration's tool for assessing risk of bias in randomised trials. BMJ 343: d5928. 
Jung, R. E., Zembic, A., Pjetursson, B. E., Zwahlen, M. \& Thoma, D. S. (2012)

Systematic review of the survival rate and the incidence of biological, technical, and aesthetic complications of single crowns on implants reported in longitudinal studies with a mean follow-up of 5 years. Clinical Oral Implants Research 23 Suppl 6: 2-21.

Liberati, A., Altman, D. G., Tetzlaff, J., Mulrow, C., Gotzsche, P. C., Ioannidis, J. P., Clarke, M., Devereaux, P. J., Kleijnen, J. \& Moher, D. (2009) The prisma statement for reporting systematic reviews and meta-analyses of studies that evaluate health care interventions: Explanation and elaboration. Annals of Internal Medicine 151: W65-94.

Moher, D., Liberati, A., Tetzlaff, J. \& Altman, D. G. (2009) Preferred reporting items for systematic reviews and meta-analyses: The prisma statement. Journal of Clinical Epidemiology 62: 1006-1012.

Nisand, D. \& Renouard, F. (2014) Short implant in limited bone volume. Periodontology 2000 66: 72-96.

Nkenke, E. \& Stelzle, F. (2009) Clinical outcomes of sinus floor augmentation for implant placement using autogenous bone or bone substitutes: A systematic review. Clinical Oral Implants Research 20 Suppl 4: 124-133.

Pistilli, R., Felice, P., Cannizzaro, G., Piatelli, M., Corvino, V., Barausse, C., Buti, J., Soardi, E. \& Esposito, M. (2013a) Posterior atrophic jaws rehabilitated with prostheses supported by $6 \mathrm{~mm}$ long $4 \mathrm{~mm}$ wide implants or by longer implants in augmented bone. One-year post-loading results from a pilot randomised controlled trial. European Journal of Oral Implantology 6: 359-372.

Pistilli, R., Felice, P., Piattelli, M., Gessaroli, M., Soardi, E., Barausse, C., Buti, J. \& Corvino, V. (2013b) Posterior atrophic jaws rehabilitated with prostheses supported by $5 \times 5 \mathrm{~mm}$ implants with a novel nanostructured calcium-incorporated titanium 
surface or by longer implants in augmented bone. One-year results from a randomised controlled trial. European Journal of Oral Implantology 6: 343-357.

Pjetursson, B. E., Tan, W. C., Zwahlen, M. \& Lang, N. P. (2008) A systematic review of the success of sinus floor elevation and survival of implants inserted in combination with sinus floor elevation. Journal of Clinical Periodontology 35: 216240.

Pjetursson, B. E., Thoma, D., Jung, R., Zwahlen, M. \& Zembic, A. (2012) A systematic review of the survival and complication rates of implant-supported fixed dental prostheses (fdps) after a mean observation period of at least 5 years. Clinical Oral Implants Research 23 Suppl 6: 22-38.

Pommer, B., Frantal, S., Willer, J., Posch, M., Watzek, G. \& Tepper, G. (2011) Impact of dental implant length on early failure rates: A meta-analysis of observational studies. Journal of Clinical Periodontology 38: 856-863.

Quaranta, A., Piemontese, M., Rappelli, G., Sammartino, G. \& Procaccini, M. (2014) Technical and biological complications related to crown to implant ratio: A systematic review. Implant Dentistry 23: 180-187.

Reinert, S., Konig, S., Bremerich, A., Eufinger, H. \& Krimmel, M. (2003) Stability of bone grafting and placement of implants in the severely atrophic maxilla. British Journal of Oral and Maxillofacial Surgery 41: 249-255.

Srinivasan, M., Vazquez, L., Rieder, P., Moraguez, O., Bernard, J. P. \& Belser, U. C. (2014) Survival rates of short (6 mm) micro-rough surface implants: A review of literature and meta-analysis. Clinical Oral Implants Research 25: 539-545.

Stricker, A., Voss, P. J., Gutwald, R., Schramm, A. \& Schmelzeisen, R. (2003) Maxillary sinus floor augmention with autogenous bone grafts to enable placement of 
sla-surfaced implants: Preliminary results after 15-40 months. Clinical Oral Implants Research 14: 207-212.

Summers, R. B. (1994) A new concept in maxillary implant surgery: The osteotome technique. Compendium 15: 152, 154-156, 158 passim; quiz 162.

Sun, H. L., Huang, C., Wu, Y. R. \& Shi, B. (2011) Failure rates of short $(</=10 \mathrm{~mm})$ dental implants and factors influencing their failure: A systematic review. International Journal of Oral and Maxillofacial Implants 26: 816-825.

Tan, W. C., Krishnaswamy, G., Ong, M. M. \& Lang, N. P. (2014) Patient-reported outcome measures after routine periodontal and implant surgical procedures. Journal of Clinical Periodontology 41: 618-624.

Tan, W. C., Lang, N. P., Zwahlen, M. \& Pjetursson, B. E. (2008) A systematic review of the success of sinus floor elevation and survival of implants inserted in combination with sinus floor elevation. Part ii: Transalveolar technique. Journal of Clinical Periodontology 35: 241-254.

Telleman, G., Raghoebar, G. M., Vissink, A., den Hartog, L., Huddleston Slater, J. J. \& Meijer, H. J. (2011) A systematic review of the prognosis of short $(<10 \mathrm{~mm}$ ) dental implants placed in the partially edentulous patient. Journal of Clinical Periodontology 38: 667-676.

Thoma, D. S., Haas, R., Tutak, M., Garcia, A., Schincaglia, G. P. \& Hämmerle, C. H. F. (2014) Randomized controlled multicenter study comparing short dental implants (6 $\mathrm{mm}$ ) versus longer dental implants (11-15 mm) in combination with sinus floor elevation procedures. Part 1: Demographics and patient-reported outcomes at 1 year of loading. Journal of Clinical Periodontology.

Truhlar, R. S., Morris, H. F., Ochi, S. \& Winkler, S. (1994) Second-stage failures related to bone quality in patients receiving endosseous dental implants: Dicrg 
interim report no. 7. Dental implant clinical research group. Implant Dentistry 3: 252-255. 


\section{Figure legends}

Figure 1. Search strategy. *For details and reasons for exclusion see reference list ("List of reviews" and "List of excluded full-text articles and the reason for exclusion")

Figure 2. Confidence intervals of survival rates for: A. included studies with longer (16-18 months) follow-up, group longer implant with sinus floor elevation. B. included studies with longer follow-up, group shorter implants.

Figure 3. Confidence intervals of survival rates for: A. included studies with shorter (8-9 months) follow-up, group longer implant with sinus floor elevation. B. included studies with shorter follow-up, group shorter implants.

\section{Table legends}

Table 1. Study and patient characteristics of the included studies

Table 2: Risk-of-bias assessment of the included studies

Table 3: Information on implants in the included studies

Table 4: Information on reconstructions in the included studies. NR, not reported

Table 5: Biological and technical complications and radiographic outcomes. NR, not reported; NA, not analyzed

Table 6: Patient-reported outcome measures and morbidity. NR, not reported 


\section{2 first electronic search: 3851 titles}

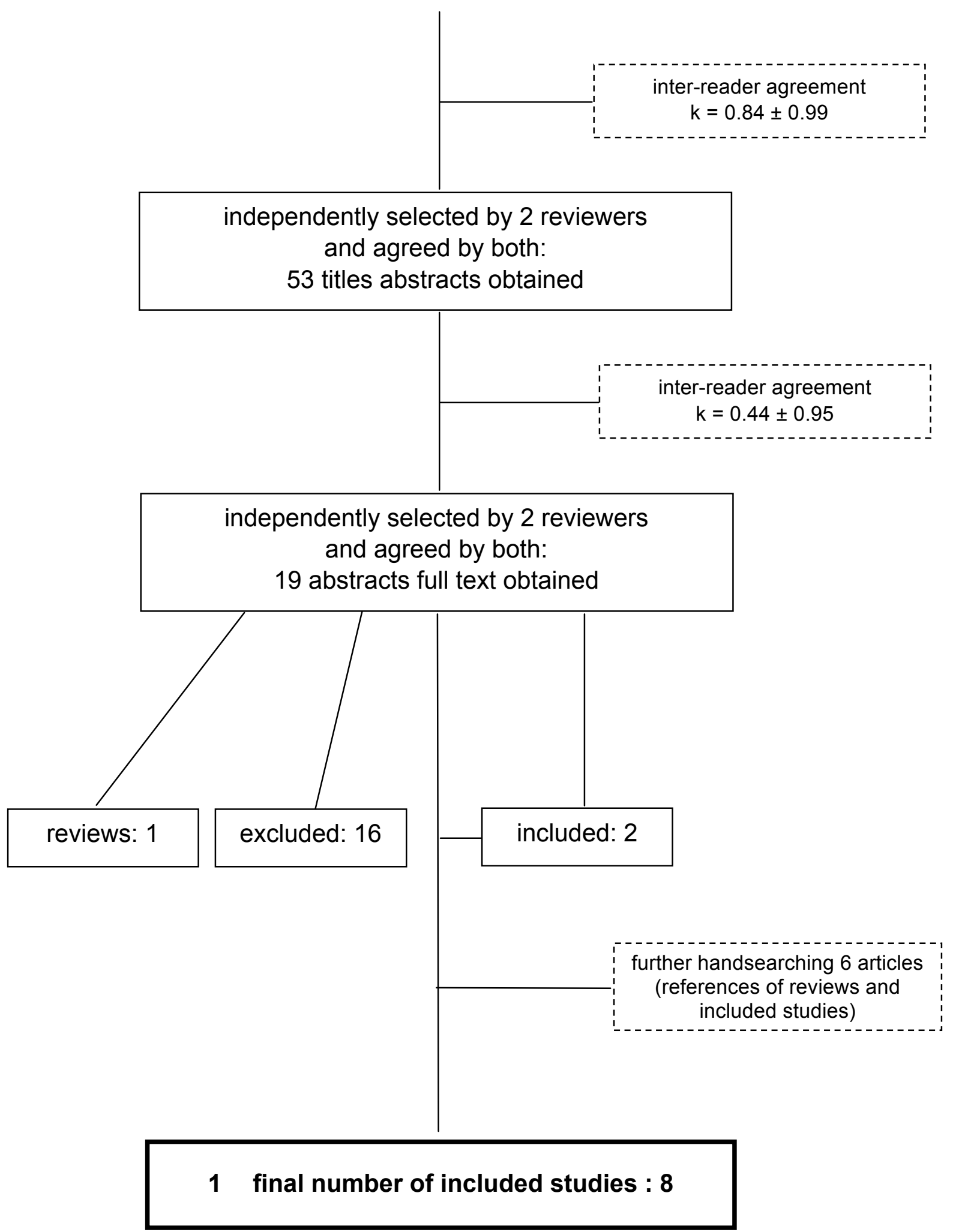

Figure 1 
Figure 2.

A.

Thoma et al. 2014

Pistilii et al. 2013a

Pistilii et al. 2013b

Guljé et al. 2014

Esposito et al. 2011

pooled studies

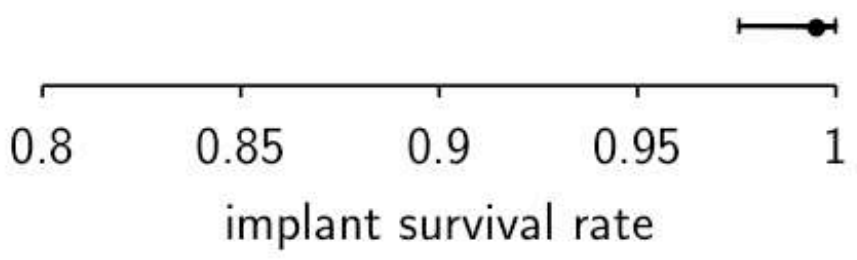

B.

Thoma et al. 2014

Pistilii et al. 2013a

Pistilii et al. 2013b

Guljé et al. 2014

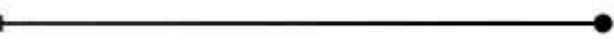

Esposito et al. 2011

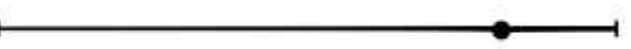

pooled studies

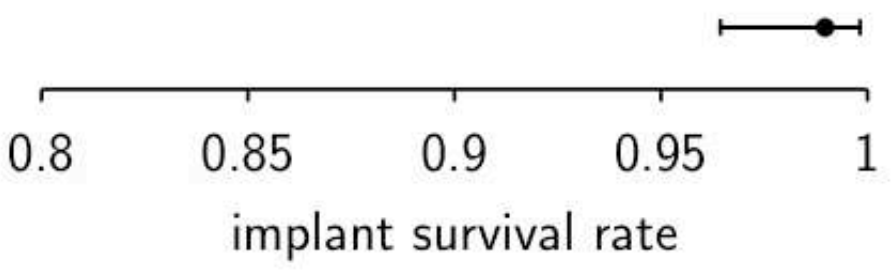


Figure 3.

A.

Felice et al. 2012

Esposito et al. 2012

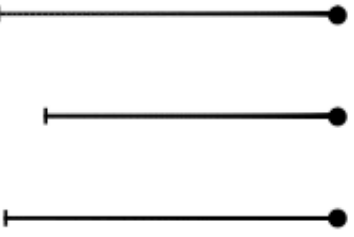

Felice et al. 2009

pooled studies

$\begin{array}{lllll}0.8 & 0.85 & 0.9 & 0.95 & 1 \\ & \text { implant survival rate } & \end{array}$

B.

Felice et al. 2012

Esposito et al. 2012

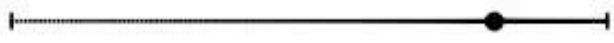

Felice et al. 2009

pooled studies

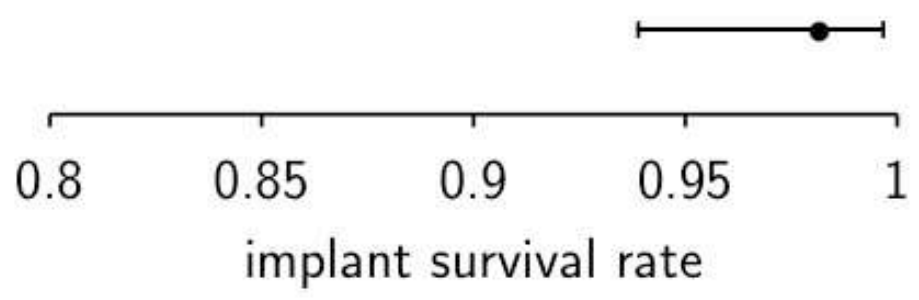


Table 1

\begin{tabular}{|c|c|c|c|c|c|c|c|c|c|}
\hline 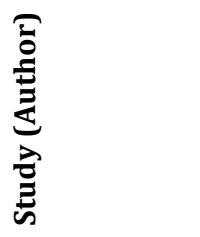 & 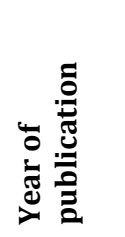 & 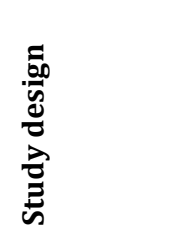 & 莞 & 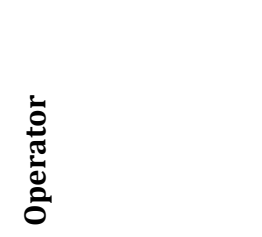 & ํํำ & 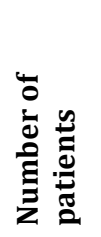 & 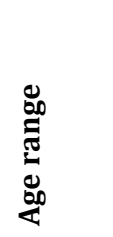 & 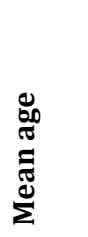 & 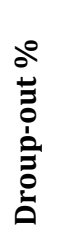 \\
\hline \multirow{2}{*}{ Thoma et al. } & \multirow{2}{*}{2014} & \multirow{2}{*}{$\begin{array}{l}\text { RCT, } \\
\text { multicenter }\end{array}$} & \multirow{2}{*}{$\begin{array}{l}\text { AstraTech } \\
\text { Osseospeed }\end{array}$} & \multirow{2}{*}{$\begin{array}{l}\text { Universities and } \\
\text { specialized clinics }\end{array}$} & $\begin{array}{l}\text { Sinus floor elevation } \\
\text { plus longer implant(s) }\end{array}$ & 50 & $20-75$ & 50.5 & 1 \\
\hline & & & & & Shorter implant(s) & 51 & $20-75$ & 50.5 & 3 \\
\hline \multirow{2}{*}{ Guljé et al. } & \multirow{2}{*}{2014} & \multirow{2}{*}{$\begin{array}{l}\text { RCT, } \\
\text { two centers }\end{array}$} & \multirow{2}{*}{$\begin{array}{l}\text { AstraTech } \\
\text { Osseospeed }\end{array}$} & \multirow{2}{*}{$\begin{array}{l}\text { University and } \\
\text { specialized clinic }\end{array}$} & $\begin{array}{l}\text { Sinus floor elevation } \\
\text { plus longer implant(s) }\end{array}$ & 20 & $29-72$ & 48.0 & 5 \\
\hline & & & & & Shorter implant(s) & 21 & $30-71$ & 50.0 & 0 \\
\hline \multirow{2}{*}{ Felice et al. } & \multirow{2}{*}{2012} & \multirow{2}{*}{$\begin{array}{l}\text { RCT, } \\
\text { two centers }\end{array}$} & \multirow{2}{*}{$\begin{array}{l}\text { ExFeel, } \\
\text { MegaGen } \\
\text { Implants }\end{array}$} & \multirow{2}{*}{$\begin{array}{l}\text { University and } \\
\text { specialized clinic }\end{array}$} & $\begin{array}{l}\text { Sinus floor elevation } \\
\text { plus longer implant(s) }\end{array}$ & 20 & $45-75$ & 58.5 & 0 \\
\hline & & & & & Shorter implant(s) & 20 & $45-70$ & 61.1 & 0 \\
\hline \multirow{2}{*}{ Pistilli et al. } & \multirow{2}{*}{$2013 b$} & \multirow{2}{*}{$\begin{array}{l}\text { RCT, } \\
\text { two centers }\end{array}$} & \multirow{2}{*}{$\begin{array}{l}\text { ExFeel, } \\
\text { MegaGen } \\
\text { Implants }\end{array}$} & \multirow{2}{*}{$\begin{array}{l}\text { University and } \\
\text { specialized clinic }\end{array}$} & $\begin{array}{l}\text { Sinus floor elevation } \\
\text { plus longer implant(s) }\end{array}$ & 20 & $45-75$ & 58.5 & 5 \\
\hline & & & & & Shorter implant(s) & 20 & $45-70$ & 61.1 & 0 \\
\hline \multirow{2}{*}{ Esposito et al. } & \multirow{2}{*}{2012} & \multirow{2}{*}{$\begin{array}{l}\text { RCT, } \\
\text { two-centers, } \\
\text { split-mouth }\end{array}$} & \multirow{2}{*}{$\begin{array}{l}\text { Southern } \\
\text { Implants }\end{array}$} & \multirow{2}{*}{$\begin{array}{l}\text { University and } \\
\text { specialized clinic }\end{array}$} & $\begin{array}{l}\text { Sinus floor elevation } \\
\text { plus longer implant(s) }\end{array}$ & 20 & $45-80$ & 57.6 & 0 \\
\hline & & & & & Shorter implant(s) & 20 & $45-80$ & 57.6 & 0 \\
\hline \multirow{2}{*}{ Pistilli et al. } & \multirow{2}{*}{$2013 a$} & \multirow{2}{*}{$\begin{array}{l}\text { RCT, } \\
\text { two-centers, } \\
\text { split-mouth }\end{array}$} & \multirow{2}{*}{$\begin{array}{l}\text { Southern } \\
\text { Implants }\end{array}$} & \multirow{2}{*}{$\begin{array}{l}\text { University and } \\
\text { specialized clinic }\end{array}$} & $\begin{array}{l}\text { Sinus floor elevation } \\
\text { plus longer implant(s) }\end{array}$ & 20 & $45-80$ & 57.6 & 0 \\
\hline & & & & & Shorter implant(s) & 20 & $45-80$ & 57.6 & 0 \\
\hline \multirow{2}{*}{ Felice et al. } & \multirow{2}{*}{2009} & \multirow{2}{*}{$\begin{array}{l}\text { RCT, } \\
\text { split-mouth }\end{array}$} & \multirow{2}{*}{$\begin{array}{l}\text { ExFeel, } \\
\text { MegaGen } \\
\text { Implants }\end{array}$} & \multirow{2}{*}{$\begin{array}{l}\text { University and } \\
\text { specialized clinic }\end{array}$} & $\begin{array}{l}\text { Sinus floor elevation } \\
\text { plus longer implant(s) }\end{array}$ & 15 & $45-70$ & 56.0 & 0 \\
\hline & & & & & Shorter implant(s) & 15 & $45-70$ & 56.0 & 0 \\
\hline
\end{tabular}


Table 2

\begin{tabular}{|c|c|c|c|c|c|c|c|c|c|}
\hline & & $\begin{array}{l}\text { Thoma et al } \\
\text { (2014) }\end{array}$ & $\begin{array}{l}\text { Gulje et al. } \\
\text { (2014) }\end{array}$ & $\begin{array}{l}\text { Felice et al. } \\
\quad(2012)\end{array}$ & $\begin{array}{l}\text { Pistilli et al. } \\
\text { (2013b) }\end{array}$ & $\begin{array}{c}\text { Esposito et al. } \\
(2012)\end{array}$ & $\begin{array}{l}\text { Pistilli et al. } \\
\text { (2013a) }\end{array}$ & $\begin{array}{l}\text { Felice et al. } \\
\quad(2009)\end{array}$ & $\begin{array}{c}\text { Esposito et al. } \\
\text { (2011) }\end{array}$ \\
\hline \multirow[b]{2}{*}{$\begin{array}{l}\text { Random } \\
\text { sequence } \\
\text { generation } \\
\text { (selection bias) }\end{array}$} & 1) & Low risk & Low risk & Low risk & Low risk & Low risk & Low risk & Low risk & Low risk \\
\hline & 2) & $\begin{array}{l}\text { A block randomization } \\
\text { sequence was used. }\end{array}$ & $\begin{array}{l}\text { A block randomization } \\
\text { sequence was used. }\end{array}$ & $\begin{array}{l}\text { A computer-generated } \\
\text { restricted random list } \\
\text { was created. }\end{array}$ & $\begin{array}{l}\text { A computer-generated } \\
\text { restricted random list } \\
\text { was created. }\end{array}$ & $\begin{array}{l}\text { A computer-generated } \\
\text { restricted random list } \\
\text { was created. }\end{array}$ & $\begin{array}{l}\text { A computer-generated } \\
\text { restricted random list } \\
\text { was created. }\end{array}$ & $\begin{array}{l}\text { A computer-generated } \\
\text { restricted random list } \\
\text { was created. }\end{array}$ & $\begin{array}{l}\text { A computer-generated } \\
\text { restricted random list } \\
\text { was created. }\end{array}$ \\
\hline \multirow[b]{2}{*}{$\begin{array}{l}\text { Allocation } \\
\text { concealment } \\
\text { (selection bias) }\end{array}$} & 1) & Low risk & Low risk & Low risk & Low risk & Low risk & Low risk & Low risk & Low risk \\
\hline & 2) & $\begin{array}{l}\text { The randomization } \\
\text { was performed at the } \\
\text { day of surgery } \\
\text { following flap } \\
\text { elevation using a } \\
\text { sealed envelope. }\end{array}$ & $\begin{array}{l}\text { A sealed envelope was } \\
\text { opened by the surgical } \\
\text { assistant at the } \\
\text { beginning of the } \\
\text { surgical procedure. }\end{array}$ & $\begin{array}{l}\text { The information on } \\
\text { how to treat each } \\
\text { patient was enclosed } \\
\text { in sequentially } \\
\text { numbered, identical, } \\
\text { opaque, sealed } \\
\text { envelopes. }\end{array}$ & $\begin{array}{l}\text { The information on } \\
\text { how to treat each } \\
\text { patient was enclosed } \\
\text { in sequentially } \\
\text { numbered, identical, } \\
\text { opaque, sealed } \\
\text { envelopes. }\end{array}$ & $\begin{array}{l}\text { The information on } \\
\text { how to treat each } \\
\text { patient was enclosed } \\
\text { in sequentially } \\
\text { numbered, identical, } \\
\text { opaque, sealed } \\
\text { envelopes. }\end{array}$ & $\begin{array}{l}\text { The information on } \\
\text { how to treat each } \\
\text { patient was enclosed } \\
\text { in sequentially } \\
\text { numbered, identical, } \\
\text { opaque, sealed } \\
\text { envelopes. }\end{array}$ & $\begin{array}{l}\text { The information on } \\
\text { how to treat each } \\
\text { patient was enclosed } \\
\text { in sequentially } \\
\text { numbered, identical, } \\
\text { opaque, sealed } \\
\text { envelopes. }\end{array}$ & $\begin{array}{l}\text { The information on } \\
\text { how to treat each } \\
\text { patient was enclosed } \\
\text { in sequentially } \\
\text { numbered, identical, } \\
\text { opaque, sealed } \\
\text { envelopes. }\end{array}$ \\
\hline \multirow[b]{2}{*}{$\begin{array}{l}\text { Blinding of } \\
\text { participants and } \\
\text { researchers } \\
\text { (performance } \\
\text { bias) }\end{array}$} & 1) & High risk & High risk & High risk & High risk & High risk & High risk & High risk & High risk \\
\hline & 2) & $\begin{array}{l}\text { Patients had the right } \\
\text { to know which } \\
\text { treatment was used. } \\
\text { Surgeons would know } \\
\text { the randomized type } \\
\text { of treatment. }\end{array}$ & $\begin{array}{l}\text { Patients had the right } \\
\text { to know which } \\
\text { treatment was used. } \\
\text { Surgeons would know } \\
\text { the randomized type } \\
\text { of treatment. }\end{array}$ & $\begin{array}{l}\text { Patients had the right } \\
\text { to know which } \\
\text { treatment was used. } \\
\text { Surgeons would know } \\
\text { the randomized type } \\
\text { of treatment. }\end{array}$ & $\begin{array}{l}\text { Patients had the right } \\
\text { to know which } \\
\text { treatment was used. } \\
\text { Surgeons would know } \\
\text { the randomized type } \\
\text { of treatment. }\end{array}$ & $\begin{array}{l}\text { Patients had the right } \\
\text { to know which } \\
\text { treatment was used. } \\
\text { Surgeons would know } \\
\text { the randomized type } \\
\text { of treatment. }\end{array}$ & $\begin{array}{l}\text { Patients had the right } \\
\text { to know which } \\
\text { treatment was used. } \\
\text { Surgeons would know } \\
\text { the randomized type } \\
\text { of treatment. }\end{array}$ & $\begin{array}{l}\text { Patients had the right } \\
\text { to know which } \\
\text { treatment was used. } \\
\text { Surgeons would know } \\
\text { the randomized type } \\
\text { of treatment. }\end{array}$ & $\begin{array}{l}\text { Patients had the right } \\
\text { to know which } \\
\text { treatment was used. } \\
\text { Surgeons would know } \\
\text { the randomized type } \\
\text { of treatment. }\end{array}$ \\
\hline \multirow[b]{2}{*}{$\begin{array}{l}\text { Blinding of } \\
\text { outcome } \\
\text { assessments } \\
\text { (detection bias) }\end{array}$} & 1) & High risk & High risk & Low risk & Low risk & Low risk & Low risk & High risk & High risk \\
\hline & 2) & $\begin{array}{l}\text { The use of an } \\
\text { independent } \\
\text { investigator to assess } \\
\text { clinical outcomes is } \\
\text { not mentioned. }\end{array}$ & $\begin{array}{l}\text { The use of an } \\
\text { independent } \\
\text { investigator to assess } \\
\text { clinical outcomes is } \\
\text { not mentioned. }\end{array}$ & $\begin{array}{l}\text { Two dentists not } \\
\text { involved in the } \\
\text { treatment of the } \\
\text { patients performed all } \\
\text { clinical } \\
\text { measurements. }\end{array}$ & $\begin{array}{l}\text { Two dentists not } \\
\text { involved in the } \\
\text { treatment of the } \\
\text { patients performed all } \\
\text { clinical } \\
\text { measurements. }\end{array}$ & $\begin{array}{l}\text { Two dentists not } \\
\text { involved in the } \\
\text { treatment of the } \\
\text { patients performed all } \\
\text { clinical } \\
\text { measurements. }\end{array}$ & $\begin{array}{l}\text { Two dentists not } \\
\text { involved in the } \\
\text { treatment of the } \\
\text { patients performed all } \\
\text { clinical } \\
\text { measurements. }\end{array}$ & $\begin{array}{l}\text { No blinding was } \\
\text { possible, because of } \\
\text { different implant } \\
\text { diameters in the } \\
\text { groups. }\end{array}$ & $\begin{array}{l}\text { No blinding was } \\
\text { possible, because of } \\
\text { different implant } \\
\text { diameters in the } \\
\text { groups. }\end{array}$ \\
\hline \multirow[b]{2}{*}{$\begin{array}{l}\text { Incomplete } \\
\text { outcome data } \\
\text { (attrition bias) }\end{array}$} & 1) & Low risk & Low risk & Low risk & Low risk & Low risk & Low risk & Low risk & Low risk \\
\hline & 2) & $\begin{array}{l}\text { Losses to follow-up } \\
\text { were disclosed } \\
\text { (4 patients: one } \\
\text { deceased, one lost to } \\
\text { follow-up, two did not } \\
\text { attend the 1-year } \\
\text { follow-up). }\end{array}$ & $\begin{array}{l}\text { Losses to follow-up } \\
\text { were disclosed } \\
\text { (1 patient deceased). }\end{array}$ & $\begin{array}{l}\text { Losses to follow-up } \\
\text { were disclosed } \\
\text { (1 patient lost to } \\
\text { follow-up). }\end{array}$ & $\begin{array}{l}\text { Losses to follow-up } \\
\text { were disclosed } \\
\text { (1 patient lost to } \\
\text { follow-up). }\end{array}$ & $\begin{array}{l}\text { Losses to follow-up } \\
\text { were disclosed (no } \\
\text { losses to follow-up). }\end{array}$ & $\begin{array}{l}\text { Losses to follow-up } \\
\text { were disclosed (no } \\
\text { losses to follow-up). }\end{array}$ & $\begin{array}{l}\text { Losses to follow-up } \\
\text { were disclosed (no } \\
\text { losses to follow-up). }\end{array}$ & $\begin{array}{l}\text { Losses to follow-up } \\
\text { were disclosed (no } \\
\text { losses to follow-up). }\end{array}$ \\
\hline \multirow[b]{2}{*}{$\begin{array}{l}\text { Selective } \\
\text { reporting } \\
\text { (reporting bias) }\end{array}$} & 1) & Low risk & Low risk & Low risk & Low risk & Low risk & Low risk & Low risk & Low risk \\
\hline & 2) & $\begin{array}{l}\text { All prespecified } \\
\text { outcomes were } \\
\text { reported. }\end{array}$ & $\begin{array}{l}\text { All prespecified } \\
\text { outcomes were } \\
\text { reported. }\end{array}$ & $\begin{array}{l}\text { All prespecified } \\
\text { outcomes were } \\
\text { reported. }\end{array}$ & $\begin{array}{l}\text { All prespecified } \\
\text { outcomes were } \\
\text { reported. }\end{array}$ & $\begin{array}{l}\text { All prespecified } \\
\text { outcomes were } \\
\text { reported. }\end{array}$ & $\begin{array}{l}\text { All prespecified } \\
\text { outcomes were } \\
\text { reported. }\end{array}$ & $\begin{array}{l}\text { All prespecified } \\
\text { outcomes were } \\
\text { reported. }\end{array}$ & $\begin{array}{l}\text { All prespecified } \\
\text { outcomes were } \\
\text { reported. }\end{array}$ \\
\hline Group & 1) & Low risk & Low risk & High risk & High risk & High risk & High risk & High risk & High risk \\
\hline
\end{tabular}




\begin{tabular}{|c|c|c|c|c|c|c|c|c|c|}
\hline imbalance & 2) & $\begin{array}{l}\text { Implants of the same } \\
\text { type and diameter } \\
\text { were used, } \\
\text { reconstructions were } \\
\text { not splinted. No } \\
\text { restrictions were } \\
\text { made regarding the } \\
\text { material and the type } \\
\text { of retention } \\
\text { (cemented/screw- } \\
\text { retained). }\end{array}$ & $\begin{array}{l}\text { Implants of the same } \\
\text { type and diameter } \\
\text { were used, materials } \\
\text { and retention type of } \\
\text { the reconstructions } \\
\text { were the same. }\end{array}$ & $\begin{array}{l}\text { Implants of the same } \\
\text { type and diameter } \\
\text { were used, but } \\
\text { reconstructions were } \\
\text { splinted. }\end{array}$ & $\begin{array}{l}\text { Implants of the same } \\
\text { type and diameter } \\
\text { were used, but } \\
\text { reconstructions were } \\
\text { splinted. }\end{array}$ & $\begin{array}{l}\text { Implants of the same } \\
\text { type and diameter } \\
\text { were used, but } \\
\text { reconstructions were } \\
\text { splinted. }\end{array}$ & $\begin{array}{l}\text { Implants of the same } \\
\text { type and diameter } \\
\text { were used, but } \\
\text { reconstructions were } \\
\text { splinted. }\end{array}$ & $\begin{array}{l}\text { Implants with } \\
\text { different diameters } \\
\text { were used and } \\
\text { reconstructions were } \\
\text { splinted. }\end{array}$ & $\begin{array}{l}\text { Implants with } \\
\text { different diameters } \\
\text { were used and } \\
\text { reconstructions were } \\
\text { splinted. }\end{array}$ \\
\hline & 1) & High risk & High risk & High risk & High risk & High risk & High risk & High risk & High risk \\
\hline Sample size & 2) & $\begin{array}{l}\text { Sample size smaller } \\
\text { than calculated by } \\
\text { power analysis. }\end{array}$ & $\begin{array}{l}\text { Sample size was } \\
\text { calculated for a } \\
\text { secondary outcome. }\end{array}$ & $\begin{array}{l}\text { No sample size } \\
\text { calculation was } \\
\text { performed. }\end{array}$ & $\begin{array}{l}\text { No sample size } \\
\text { calculation was } \\
\text { performed. }\end{array}$ & $\begin{array}{l}\text { Sample size was } \\
\text { calculated for a } \\
\text { secondary outcome }\end{array}$ & $\begin{array}{l}\text { Sample size was } \\
\text { calculated for a } \\
\text { secondary outcome }\end{array}$ & $\begin{array}{l}\text { Sample size was } \\
\text { calculated for a } \\
\text { secondary outcome }\end{array}$ & $\begin{array}{l}\text { Sample size was } \\
\text { calculated for a } \\
\text { secondary outcome }\end{array}$ \\
\hline \multirow[b]{2}{*}{ Follow-up time } & 1) & High risk & High risk & High risk & High risk & High risk & High risk & High risk & High risk \\
\hline & 2) & One year follow-up & One year follow-up & 4 months follow-up & One year follow-up & 5 months follow-up & One year follow-up & 4 month follow-up & One year follow-up \\
\hline \multirow{2}{*}{$\begin{array}{l}\text { Radiographic } \\
\text { outcome }\end{array}$} & 1) & High risk & High risk & High risk & High risk & High risk & High risk & High risk & High risk \\
\hline & 2) & No blinding possible & No blinding possible & No blinding possible & No blinding possible & No blinding possible & No blinding possible & No blinding possible & No blinding possible \\
\hline \multirow[b]{2}{*}{ Clinician bias } & 1) & High risk & High risk & High risk & High risk & High risk & High risk & High risk & High risk \\
\hline & 2) & $\begin{array}{l}\text { The study did not } \\
\text { address which } \\
\text { clinicians performed } \\
\text { the treatments. }\end{array}$ & $\begin{array}{l}\text { The study did not } \\
\text { address which } \\
\text { clinicians performed } \\
\text { the treatments. }\end{array}$ & $\begin{array}{l}\text { Two surgeons / } \\
\text { prosthodontists } \\
\text { performed the } \\
\text { treatments. }\end{array}$ & $\begin{array}{l}\text { Two surgeons / } \\
\text { prosthodontists } \\
\text { performed the } \\
\text { treatments. }\end{array}$ & $\begin{array}{l}\text { Two surgeons / } \\
\text { prosthodontists } \\
\text { performed the } \\
\text { treatments. }\end{array}$ & $\begin{array}{l}\text { Two surgeons / } \\
\text { prosthodontists } \\
\text { performed the } \\
\text { treatments. }\end{array}$ & $\begin{array}{l}\text { One surgeon, the } \\
\text { study did not address } \\
\text { which clinician } \\
\text { performed the } \\
\text { prosthetic treatment. }\end{array}$ & $\begin{array}{l}\text { One surgeon, the } \\
\text { study did not address } \\
\text { which clinician } \\
\text { performed the } \\
\text { prosthetic treatment. }\end{array}$ \\
\hline
\end{tabular}

1) Authors' judgment

2) Support for judgment 
Table 3

\begin{tabular}{|c|c|c|c|c|c|c|c|c|c|c|c|c|c|c|}
\hline 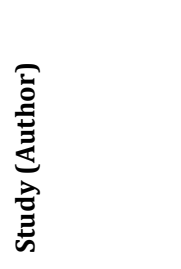 & 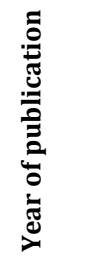 & 言 & 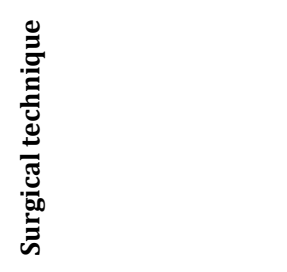 & 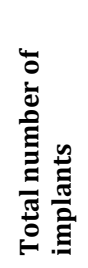 & 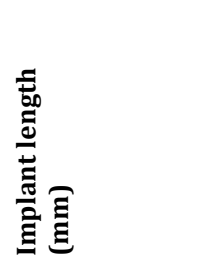 & 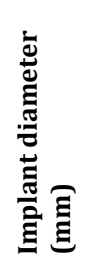 & 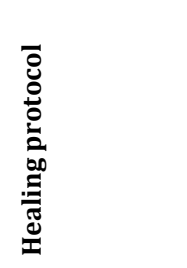 & 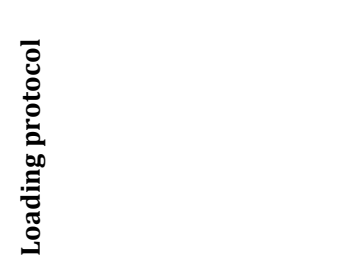 & 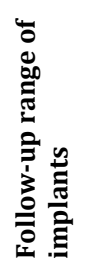 & 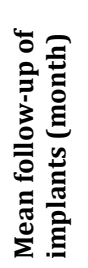 & 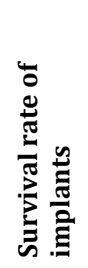 & 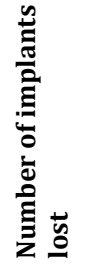 & 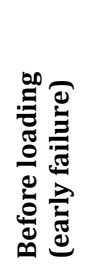 & 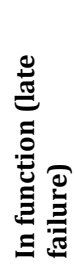 \\
\hline \multirow[t]{2}{*}{ Thoma et al. } & \multirow[t]{2}{*}{2014} & $\begin{array}{l}\text { Sinus floor } \\
\text { elevation plus } \\
\text { longer implant(s) }\end{array}$ & $\begin{array}{l}\text { Lateral window } \\
\text { technique with } \\
\text { simultaneous implant } \\
\text { placement }\end{array}$ & 70 & $11-15$ & 4 & $\begin{array}{l}\text { submerged } \\
\text { and } \\
\text { transmucosal } \\
\end{array}$ & 6 months & NR & 18 & $100 \%$ & 0 & 0 & 0 \\
\hline & & Shorter implant(s) & Shorter implant(s) & 67 & 6 & 4 & $\begin{array}{l}\text { submerged } \\
\text { and } \\
\text { transmucosal }\end{array}$ & 6 months & NR & 18 & $100 \%$ & 0 & 0 & 0 \\
\hline \multirow[t]{2}{*}{ Guljé et al. } & \multirow[t]{2}{*}{2014} & $\begin{array}{l}\text { Sinus floor } \\
\text { elevation plus } \\
\text { longer implant(s) }\end{array}$ & $\begin{array}{l}\text { Lateral window } \\
\text { technique with } \\
\text { simultaneous implant } \\
\text { placement }\end{array}$ & 20 & 11 & 4 & submerged & 4 months & NR & 16 & $100 \%$ & 0 & 0 & 0 \\
\hline & & Shorter implant(s) & Shorter implant(s) & 21 & 6 & 4 & submerged & 4 months & NR & 16 & $100 \%$ & 0 & 0 & 0 \\
\hline \multirow[t]{2}{*}{ Felice et al. } & \multirow[t]{2}{*}{2012} & $\begin{array}{l}\text { Sinus floor } \\
\text { elevation plus } \\
\text { longer implant(s) }\end{array}$ & $\begin{array}{l}\text { Lateral window } \\
\text { technique with } \\
\text { simultaneous implant } \\
\text { placement }\end{array}$ & 37 & $\begin{array}{l}11.9(=\text { mean }) \\
\text { at least } 10\end{array}$ & 5 & submerged & $\begin{array}{l}4 \text { months (provisional); } \\
8 \text { months (final prosthesis) }\end{array}$ & NR & 8 & $100 \%$ & 0 & 0 & 0 \\
\hline & & Shorter implant(s) & Shorter implant(s) & 36 & 5 & 5 & submerged & $\begin{array}{l}4 \text { months (provisional); } \\
8 \text { months (final prosthesis) }\end{array}$ & NR & 8 & $97 \%$ & 1 & 0 & 1 \\
\hline \multirow[t]{2}{*}{ Pistilli et al. } & \multirow[t]{2}{*}{$\begin{array}{c}2013 \\
b\end{array}$} & $\begin{array}{l}\text { Sinus floor } \\
\text { elevation plus } \\
\text { longer implant(s) }\end{array}$ & $\begin{array}{l}\text { Lateral window } \\
\text { technique with } \\
\text { simultaneous implant } \\
\text { placement }\end{array}$ & 37 & $\begin{array}{l}11.9(=\text { mean }) \\
\text { at least } 10\end{array}$ & 5 & submerged & $\begin{array}{l}4 \text { months (provisional); } \\
8 \text { months (final prosthesis) }\end{array}$ & NR & 16 & $100 \%$ & 0 & 0 & 0 \\
\hline & & Shorter implant(s) & Shorter implant(s) & 36 & 5 & 5 & submerged & $\begin{array}{l}4 \text { months (provisional); } \\
8 \text { months (final prosthesis) }\end{array}$ & NR & 16 & $97 \%$ & 1 & 0 & 1 \\
\hline \multirow[t]{2}{*}{ Esposito et al. } & \multirow[t]{2}{*}{2012} & $\begin{array}{l}\text { Sinus floor } \\
\text { elevation plus } \\
\text { longer implant(s) }\end{array}$ & $\begin{array}{l}\text { Lateral window } \\
\text { technique with } \\
\text { simultaneous implant } \\
\text { placement }\end{array}$ & 44 & $\begin{array}{l}11.8(=\text { mean); } \\
\text { at least } 10\end{array}$ & 4 & submerged & $\begin{array}{l}4 \text { months (provisional); } \\
8 \text { months (final prosthesis) }\end{array}$ & NR & 9 & $100 \%$ & 0 & 0 & 0 \\
\hline & & Shorter implant(s) & Shorter implant(s) & 39 & 6 & 4 & submerged & $\begin{array}{l}4 \text { months (provisional); } \\
8 \text { months (final prosthesis) }\end{array}$ & NR & 9 & $100 \%$ & 0 & 0 & 0 \\
\hline \multirow[t]{2}{*}{ Pistilli et al. } & \multirow{2}{*}{$\begin{array}{c}2013 \\
\mathrm{a}\end{array}$} & $\begin{array}{l}\text { Sinus floor } \\
\text { elevation plus } \\
\text { longer implant(s) }\end{array}$ & $\begin{array}{l}\text { Lateral window } \\
\text { technique with } \\
\text { simultaneous implant } \\
\text { placement }\end{array}$ & 44 & $\begin{array}{l}11.8(=\text { mean); } \\
\text { at least } 10\end{array}$ & 4 & submerged & $\begin{array}{l}4 \text { months (provisional); } \\
8 \text { months (final prosthesis) }\end{array}$ & NR & 16 & $100 \%$ & 0 & 0 & 0 \\
\hline & & Shorter implant(s) & Shorter implant(s) & 39 & 6 & 4 & submerged & $\begin{array}{l}4 \text { months (provisional); } \\
8 \text { months (final prosthesis) }\end{array}$ & NR & 16 & $100 \%$ & 0 & 0 & 0 \\
\hline
\end{tabular}




\begin{tabular}{|c|c|c|c|c|c|c|c|c|c|c|c|c|c|c|}
\hline \multirow[t]{2}{*}{ Felice et al. } & \multirow[t]{2}{*}{2009} & $\begin{array}{l}\text { Sinus floor } \\
\text { elevation plus } \\
\text { longer implant(s) }\end{array}$ & $\begin{array}{l}\text { Lateral window } \\
\text { technique with staged } \\
\text { implant placement } \\
\text { (after } 4 \text { months) }\end{array}$ & 38 & $\begin{array}{l}12.4 \text { (=mean); } \\
\text { at least } 10\end{array}$ & 4 & submerged & $\begin{array}{l}4 \text { months (provisional); } \\
8 \text { months (final prosthesis) }\end{array}$ & NR & 8 & $100 \%$ & 0 & 0 & 0 \\
\hline & & Shorter implant(s) & Shorter implant(s) & 34 & 5 & 6 & submerged & $\begin{array}{l}4 \text { months (provisional); } \\
8 \text { months (final prosthesis) }\end{array}$ & NR & 8 & $97 \%$ & 1 & 1 & 0 \\
\hline \multirow[t]{2}{*}{ Esposito et al. } & \multirow[t]{2}{*}{2011} & $\begin{array}{l}\text { Sinus floor } \\
\text { elevation plus } \\
\text { longer implant(s) }\end{array}$ & $\begin{array}{l}\text { Lateral window } \\
\text { technique with staged } \\
\text { implant placement } \\
\text { (after } 4 \text { months) }\end{array}$ & 38 & $\begin{array}{l}12.4(=\text { mean }) \\
\text { at least } 10\end{array}$ & 4 & submerged & $\begin{array}{l}4 \text { months (provisional); } \\
8 \text { months (final prosthesis) }\end{array}$ & NR & 16 & $\begin{array}{c}97.4 \\
\%\end{array}$ & 1 & 0 & 1 \\
\hline & & Shorter implant(s) & Shorter implant(s) & 34 & 5 & 6 & submerged & $\begin{array}{l}4 \text { months (provisional); } \\
8 \text { months (final prosthesis) }\end{array}$ & NR & 16 & $97 \%$ & 1 & 1 & 0 \\
\hline
\end{tabular}


Table 4

\begin{tabular}{|c|c|c|c|c|c|c|c|c|}
\hline 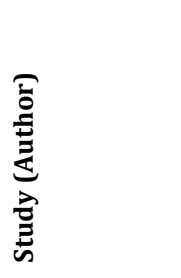 & 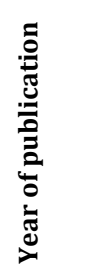 & 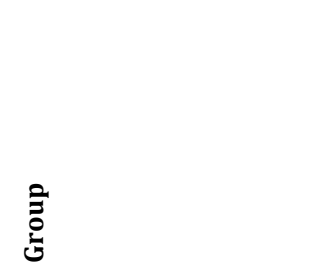 & 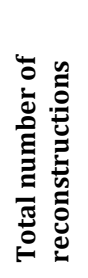 & 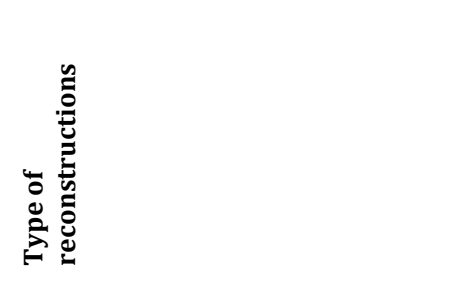 & 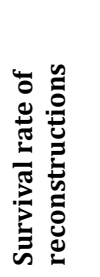 & 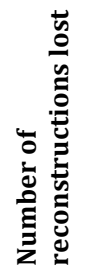 & 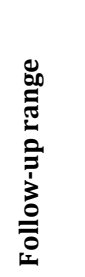 & 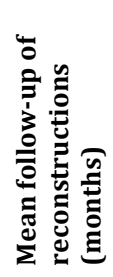 \\
\hline \multirow{2}{*}{ Thoma et al. } & \multirow{2}{*}{2014} & $\begin{array}{l}\text { Sinus floor elevation plus } \\
\text { longer implant(s) }\end{array}$ & 70 & fixed, single crown(s) & $100 \%$ & 0 & NR & 12 \\
\hline & & Shorter implant(s) & 65 & fixed, single crown(s) & $100 \%$ & 0 & NR & 12 \\
\hline \multirow{2}{*}{ Guljé et al. } & \multirow{2}{*}{2014} & $\begin{array}{l}\text { Sinus floor elevation plus } \\
\text { longer implant(s) }\end{array}$ & 20 & fixed, single crown(s) & $100 \%$ & 0 & NR & 12 \\
\hline & & Shorter implant(s) & 21 & fixed, single crown(s) & $100 \%$ & 0 & NR & 12 \\
\hline \multirow{2}{*}{ Felice et al. } & \multirow{2}{*}{2012} & $\begin{array}{l}\text { Sinus floor elevation plus } \\
\text { longer implant(s) }\end{array}$ & NR & fixed; single crowns or splinted FDPs & $100 \%$ & 0 & NR & 0 \\
\hline & & Shorter implant(s) & NR & fixed; single crowns or splinted FDPs & NR & 1 & NR & 0 \\
\hline \multirow{2}{*}{ Pistilli et al. } & \multirow{2}{*}{$2013 b$} & $\begin{array}{l}\text { Sinus floor elevation plus } \\
\text { longer implant(s) }\end{array}$ & NR & fixed; single crowns or splinted FDPs & $100 \%$ & 0 & NR & 8 \\
\hline & & Shorter implant(s) & NR & fixed; single crowns or splinted FDPs & $97 \%$ & 1 & NR & 8 \\
\hline \multirow{2}{*}{ Esposito et al. } & \multirow{2}{*}{2012} & $\begin{array}{l}\text { Sinus floor elevation plus } \\
\text { longer implant(s) }\end{array}$ & NR & fixed; single crowns or splinted FDPs & $100 \%$ & 0 & NR & 1 \\
\hline & & Shorter implant(s) & NR & fixed; single crowns or splinted FDPs & $100 \%$ & 0 & NR & 1 \\
\hline \multirow{2}{*}{ Pistilli et al. } & \multirow{2}{*}{$2013 a$} & $\begin{array}{l}\text { Sinus floor elevation plus } \\
\text { longer implant(s) }\end{array}$ & NR & fixed; single crowns or splinted FDPs & $100 \%$ & 0 & NR & 12 \\
\hline & & Shorter implant(s) & NR & fixed; single crowns or splinted FDPs & $100 \%$ & 0 & NR & 12 \\
\hline \multirow{2}{*}{ Felice et al. } & \multirow{2}{*}{2009} & $\begin{array}{l}\text { Sinus floor elevation plus } \\
\text { longer implant(s) }\end{array}$ & NR & fixed; single crowns or splinted FDPs & NR & NR & NR & 0 \\
\hline & & Shorter implant(s) & NR & fixed; single crowns or splinted FDPs & NR & NR & NR & 0 \\
\hline \multirow{2}{*}{ Esposito et al. } & \multirow{2}{*}{2011} & $\begin{array}{l}\text { Sinus floor elevation plus } \\
\text { longer implant(s) }\end{array}$ & NR & fixed; single crowns or splinted FDPs & NR & NR & NR & 8 \\
\hline & & Shorter implant(s) & NR & fixed; single crowns or splinted FDPs & NR & NR & NR & 8 \\
\hline
\end{tabular}


Table 5

\begin{tabular}{|c|c|c|c|c|c|c|c|c|c|c|c|}
\hline 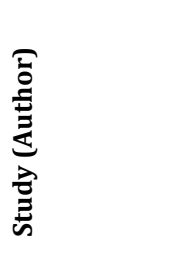 & 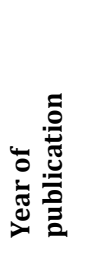 & 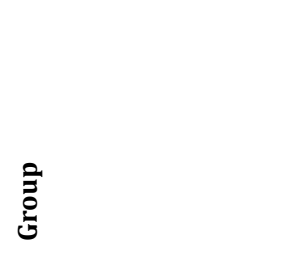 & 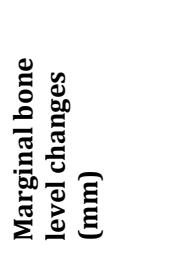 & 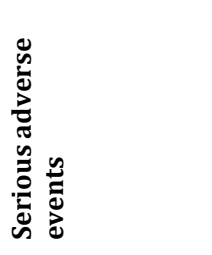 & 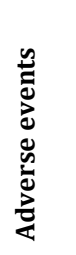 & 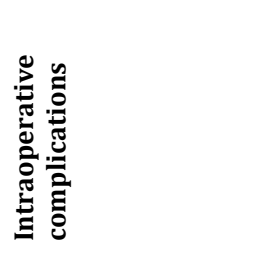 & 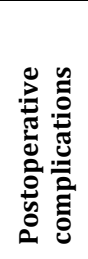 & 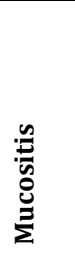 & 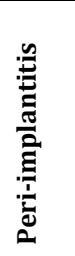 & 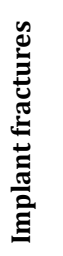 & 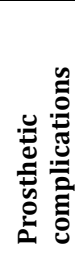 \\
\hline \multirow{2}{*}{ Thoma et al. } & \multirow{2}{*}{2014} & $\begin{array}{l}\text { Sinus floor elevation } \\
\text { plus longer implant(s) }\end{array}$ & NR & $\begin{array}{l}1 \text { (not related to } \\
\text { treatment) }\end{array}$ & 14 & NR & 7 & 1 & 0 & 0 & 3 \\
\hline & & Shorter implant(s) & NR & $\begin{array}{c}1 \text { (not related to } \\
\text { treatment) }\end{array}$ & 7 & NR & 2 & 0 & 0 & 0 & 3 \\
\hline \multirow{2}{*}{ Guljé et al. } & \multirow{2}{*}{2014} & $\begin{array}{l}\text { Sinus floor elevation } \\
\text { plus longer implant(s) }\end{array}$ & $-0.1(\mathrm{SD}=0.3)$ & $\begin{array}{c}1 \text { (not related to } \\
\text { treatment) }\end{array}$ & 0 & 0 & 0 & 0 & 0 & 0 & 0 \\
\hline & & Shorter implant(s) & $-0.1(\mathrm{SD}=0.2)$ & 0 & 0 & 0 & 0 & 0 & 0 & 0 & 0 \\
\hline \multirow{2}{*}{ Felice et al. } & \multirow{2}{*}{2012} & $\begin{array}{l}\text { Sinus floor elevation } \\
\text { plus longer implant(s) }\end{array}$ & NR & NR & 5 & $\begin{array}{c}5 \text { (sinus membrane } \\
\text { perforations) }\end{array}$ & 0 & NR & NR & 0 & NA \\
\hline & & Shorter implant(s) & NR & NR & 0 & 0 & 0 & NR & NR & 0 & NA \\
\hline \multirow{2}{*}{ Pistilli et al. } & \multirow{2}{*}{$2013 b$} & $\begin{array}{l}\text { Sinus floor elevation } \\
\text { plus longer implant(s) }\end{array}$ & $\begin{array}{c}-1.15 \\
(\mathrm{SD}=0.12) \\
\end{array}$ & NR & 5 & $\begin{array}{l}5 \text { (sinus membrane } \\
\text { perforations) }\end{array}$ & 0 & NR & NR & 0 & 0 \\
\hline & & Shorter implant(s) & $\begin{array}{c}-0.87 \\
(\mathrm{SD}=0.07)\end{array}$ & NR & 0 & 0 & 0 & NR & NR & 0 & 1 \\
\hline \multirow{2}{*}{ Esposito et al. } & \multirow{2}{*}{2012} & $\begin{array}{l}\text { Sinus floor elevation } \\
\text { plus longer implant(s) }\end{array}$ & NR & NR & 4 & $\begin{array}{l}4 \text { (sinus membrane } \\
\text { perforations) }\end{array}$ & 0 & NR & NR & 0 & 0 \\
\hline & & Shorter implant(s) & NR & NR & 0 & 0 & 0 & NR & NR & 0 & 0 \\
\hline \multirow{2}{*}{ Pistilli et al. } & \multirow{2}{*}{$2013 a$} & $\begin{array}{l}\text { Sinus floor elevation } \\
\text { plus longer implant(s) }\end{array}$ & $\begin{array}{c}-1.09 \\
(\mathrm{SD}=0.05)\end{array}$ & NR & 4 & $\begin{array}{l}4 \text { (sinus membrane } \\
\text { perforations) }\end{array}$ & 0 & $\mathrm{NR}$ & NR & 0 & 0 \\
\hline & & Shorter implant(s) & $\begin{array}{c}-1.02 \\
(\mathrm{SD}=0.06)\end{array}$ & NR & 0 & 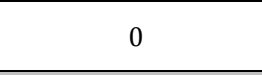 & 0 & NR & NR & 0 & 0 \\
\hline \multirow{2}{*}{ Felice et al. } & \multirow{2}{*}{2009} & $\begin{array}{l}\text { Sinus floor elevation } \\
\text { plus longer implant(s) }\end{array}$ & NR & NR & 1 & $\begin{array}{c}1 \text { (sinus membrane } \\
\text { perforations) }\end{array}$ & 0 & NR & 0 & 0 & NA \\
\hline & & Shorter implant(s) & NR & NR & 3 & $\begin{array}{c}3 \text { (sinus membrane } \\
\text { perforations) }\end{array}$ & 0 & NR & 1 & 0 & NA \\
\hline \multirow{2}{*}{ Esposito et al. } & \multirow{2}{*}{2011} & $\begin{array}{l}\text { Sinus floor elevation } \\
\text { plus longer implant(s) }\end{array}$ & NR & NR & 1 & $\begin{array}{c}1 \text { (sinus membrane } \\
\text { perforations) }\end{array}$ & 0 & NR & 1 & 0 & NR \\
\hline & & Shorter implant(s) & NR & NR & 3 & $\begin{array}{l}3 \text { (sinus membrane } \\
\text { perforations) }\end{array}$ & 0 & NR & 0 & 0 & NR \\
\hline
\end{tabular}


Table 6

\begin{tabular}{|c|c|c|c|c|c|c|c|c|c|c|c|c|}
\hline 胥离 & 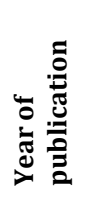 & 产 & 气 & 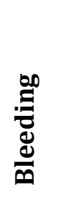 & 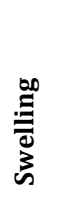 & 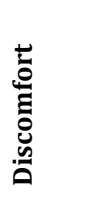 & 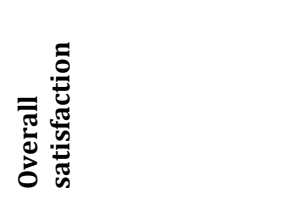 & 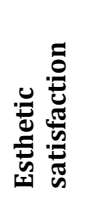 & $\begin{array}{l}\stackrel{\overrightarrow{0}}{0} \\
\dot{0} \\
\dot{0} \\
\sum\end{array}$ & $\frac{n}{\tilde{c}}$ & 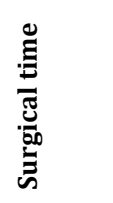 & 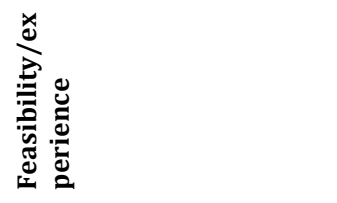 \\
\hline \multirow[b]{2}{*}{ Thoma et al. } & \multirow[b]{2}{*}{2014} & $\begin{array}{l}\text { Sinus floor elevation } \\
\text { plus longer implant(s) }\end{array}$ & NR & NR & NR & NR & NR & NR & $\begin{array}{l}\text { OHIP-49: statistically significant changes } \\
\text { from screening to suture removal for most } \\
\text { of the dimensions }\end{array}$ & $\begin{array}{l}1946 \\
\text { Euros }\end{array}$ & $75 \mathrm{~min}$ & Experienced surgeons \\
\hline & & Shorter implant(s) & NR & NR & NR & NR & NR & NR & $\begin{array}{l}\text { OHIP-49: no statistically significant changes } \\
\text { from screening to suture removal for most } \\
\text { of the dimensions }\end{array}$ & $\begin{array}{c}941 \\
\text { Euros }\end{array}$ & $53 \mathrm{~min}$ & Experienced surgeons \\
\hline \multirow{2}{*}{ Guljé et al. } & \multirow{2}{*}{2014} & $\begin{array}{l}\text { Sinus floor elevation } \\
\text { plus longer implant(s) }\end{array}$ & NR & NR & NR & $\begin{array}{c}0.0 \\
\text { (VAS) }\end{array}$ & $9.2 \pm 0.71(\mathrm{VAS})$ & $100 \%$ & NR & NR & NR & Experienced surgeons \\
\hline & & Shorter implant(s) & NR & NR & NR & $\begin{array}{l}0.0 \\
\text { (VAS) }\end{array}$ & $9.5 \pm 0.71(\mathrm{VAS})$ & $100 \%$ & NR & NR & NR & Experienced surgeons \\
\hline \multirow{2}{*}{ Felice et al. } & \multirow{2}{*}{2012} & $\begin{array}{l}\text { Sinus floor elevation } \\
\text { plus longer implant(s) }\end{array}$ & NR & NR & NR & NR & NR & NR & NR & NR & NR & Two experienced surgeons \\
\hline & & Shorter implant(s) & NR & NR & NR & NR & NR & NR & NR & NR & NR & Two experienced surgeons \\
\hline \multirow{2}{*}{ Pistilli et al. } & \multirow{2}{*}{$2013 b$} & $\begin{array}{l}\text { Sinus floor elevation } \\
\text { plus longer implant(s) }\end{array}$ & NR & NR & NR & NR & NR & NR & NR & NR & NR & Two experienced surgeons \\
\hline & & Shorter implant(s) & NR & NR & NR & NR & NR & NR & NR & NR & NR & Two experienced surgeons \\
\hline \multirow{2}{*}{ Esposito et al. } & \multirow{2}{*}{2012} & $\begin{array}{l}\text { Sinus floor elevation } \\
\text { plus longer implant(s) }\end{array}$ & NR & NR & NR & NR & $\begin{array}{l}\text { 5/20 patients: both } \\
\text { procedures equally } \\
\text { acceptable }\end{array}$ & NR & NR & NR & NR & Two experienced surgeons \\
\hline & & Shorter implant(s) & NR & NR & NR & NR & $\begin{array}{l}15 / 20 \text { patients } \\
\text { preferred short } \\
\text { implants }\end{array}$ & NR & NR & NR & NR & Two experienced surgeons \\
\hline \multirow{2}{*}{ Pistilli et al. } & \multirow{2}{*}{$2013 a$} & $\begin{array}{l}\text { Sinus floor elevation } \\
\text { plus longer implant(s) }\end{array}$ & NR & NR & NR & NR & $\begin{array}{l}5 / 20 \text { patients: both } \\
\text { procedures equally } \\
\text { acceptable }\end{array}$ & NR & NR & NR & NR & 5 experienced surgeons \\
\hline & & Shorter implant(s) & NR & NR & NR & NR & $\begin{array}{l}15 / 20 \text { patients } \\
\text { preferred short } \\
\text { implants }\end{array}$ & NR & NR & NR & NR & 5 experienced surgeons \\
\hline \multirow{2}{*}{ Felice et al. } & \multirow{2}{*}{2009} & $\begin{array}{l}\text { Sinus floor elevation } \\
\text { plus longer implant(s) }\end{array}$ & NR & NR & NR & NR & $\begin{array}{l}\text { All patients rated both } \\
\text { procedures equal } \\
\text { (no preference) }\end{array}$ & NR & NR & NR & NR & One experienced surgeon \\
\hline & & Shorter implant(s) & NR & NR & NR & NR & $\begin{array}{l}\text { All patients rated both } \\
\text { procedures equal } \\
\text { (no preference) }\end{array}$ & NR & NR & NR & NR & One experienced surgeon \\
\hline Esposito et al. & 2011 & $\begin{array}{l}\text { Sinus floor elevation } \\
\text { plus longer implant(s) }\end{array}$ & NR & NR & NR & NR & NR & NR & NR & NR & NR & One experienced surgeon \\
\hline
\end{tabular}




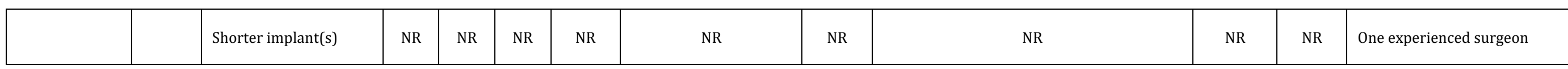

